\title{
An Upper Mississippian echinoderm microfauna from the Genicera Formation of northern León (Carboniferous, Cantabrian Mountains, $\mathbf{N}$ Spain)
}

\author{
Joachim PABST* \& Hans-Georg HERBIG
}

Institut für Geologie und Mineralogie, Universität zu Köln. Zülpicher Str. 49a, D-50674 Köln. jpabst2@uni-koeln.de; herbig.paleont@uni-koeln.de

* Corresponding author

Pabst, J. \& Herbig, H. 2020. An Upper Mississippian echinoderm microfauna from the Genicera Formation of northern León (Carboniferous, Cantabrian Mountains, N Spain). [Microfauna de equinodermos del Misisipiense Superior de la Formación Genicera del norte de León (Carbonífero, Cordillera Cantábrica, N de España)]. Spanish Journal of Palaeontology, 35 (1), 47-76.

Manuscript received 30 January 2019

Manuscript accepted 12 November 2019 https://doi.org/10.7203/sjp.35.1.17116

(C) Sociedad Española de Paleontología ISSN 2255-0550

\begin{abstract}
For the first time an echinoderm microfauna is recorded from the cephalopod limestone facies ('griotte facies') of the lower Carboniferous (Mississippian) Genicera Fm. (Alba Fm.). The formation is widespread in the Cantabrian Mountains in NW Spain, but the ossicles are from some sections in the surroundings of the Bernesga valley in northern León. They have been derived from insoluble acetic acid residues from samples of the upper and especially of the uppermost part of the formation (Canalón Mb. and Millaró Beds). The microfauna include taxonomically treated wheel-shaped ossicles, sieve-plates and rods of holothurians, goniodonts of ophiocistioids, and ophiuroid and stenuroid skeletal elements. From the Palaeozoic of Spain Ophiocistioidea, Stenuroidea, Apodida (Holothuroidea), and allagecrinids (microcrinoids) are first reported. Here, we describe two new species: Linguaserra heidii n. sp. (Ophiocistioidea) and Calclyra bifida n. sp. (Ophiuroidea). Indeterminate echinoderm remains are also figured and discussed. The findings stress the importance of a diverse but still poorly documented
\end{abstract}

\section{RESUMEN}

Por primera vez se describe una microfauna de equinodermos de las calizas nodulosas con cefalópodos ("griotte facies") de la Formación Genicera (Formación Alba) del Carbonífero inferior (Misisipiense). Si bien esta formación es de considerable extensión en la Cordillera Cantábrica en el norte de España, los oscículos descritos solo proceden de unas secciones de los alrededores del valle de Bernesga al norte de León. Tras un tratamiento con ácido acético, éstos han sido identificados en los residuos insolubles de pruebas de la parte superior y especialmente de los últimos niveles de dicha formación (Miembro Canalón y Capas de Millaró). La microfauna incluye oscículos con forma de rueda, placas perforadas y bastones de los holoturoideos, goniodontos de los ofiocistioideos y elementos de ofiuroideos y stenuroideos, todos ellos taxonomicamente estudiados. Varios elementos de la microfauna representan hallazgos inéditos del Paleozoico de España, incluso de sus correspondientes rangos más altos como Ofiocistioidea, Stenuroidea, Apodida (Holothuroidea), y allagecrinidos (microcrinoideos). En este trabajo describimos 
echinoderm fauna in Upper Mississippian psychrospheric pelagic environments.

Keywords: Viséan, Serpukhovian, cephalopod limestone, carbonate microfacies, echinoderm ossicles, taxonomy. dos nuevas especies: Linguaserra heidii $\mathrm{n}$. sp. (Ophiocistioidea) y Calclyra bifida n. sp. (Ophiuroidea). Además se expone y discute unos restos de equinodermos indeterminados. Estos hallazgos reivindican la importancia de una diversa fauna de equinodermos todavía insuficientemente documentada del ámbito psicrosférico pelágico del Misisipiense Superior.

Palabras clave: Viséense, Serpukhoviense, calizas con cefalópodos, microfacies de carbonatos, oscículos de equinodermos, taxonomía.

\section{INTRODUCTION}

The Cantabrian Mountains form the most external zone of the northern branch of the Spanish Variscides, named Cantabrian Zone (Lotze, 1945), which is characterized by a complex pattern of thrust slices and nappes (Julivert, 1971). During most of the Mississippian period that foreland basin passed through the pre-orogenic starved basin phase characterized by pelagic deeper water deposits (Kullmann et al., 1977; Marcos \& Pulgar, 1982; Colmenero et al., 2002). During the mid and late Tournaisian, some meters thick black shales developed (Vegamián Fm.) (Comte, 1959). They are overlain by condensed pelagic nodular cephalopod limestone ('griotte') of the Genicera Fm. (Wagner et al., 1971), respectively Alba Fm. (Comte, 1959), including locally a subordinate package of siliceous shales and cherts. The formation does not exceed a thickness of $55 \mathrm{~m}$ in spite of its extended stratigraphic range, reaching from the diachronous base between latest Tournaisian and earliest Viséan (Scaliognathus anchoralis to Gnathodus texanus zone) to the late Serpukhovian (Gn. truyolsi zone). Among numerous studies, some relevant biostratigraphic papers are from van Adrichem Boogaert (1967), Higgins (1971), Higgins \& WagnerGentis (1982), García-López \& Sanz-López (2002) and Nemyrovska (2005). In the last decade, uppermost Viséan and Serpukhovian conodonts and smaller foraminifers of the Genicera Fm. gained attention due to their importance for definition of a GSSP at the Viséan-Serpukhovian boundary (e.g. Sanz-López et al., 2007; Cózar et al., 2016; Sanz-López et al., 2019). The Genicera Fm. and its lateral equivalents, e.g. the Carrión Fm. of Nemyrovska (2005) from the Palentine realm, are widespread in all tectonic units of the Cantabrian Mountains containing Mississippian rocks. Its sediments represent the largest preserved late Palaeozoic pelagic carbonate platform of the EuropeanNorth African Variscides. However, analogous facies are also widespread in other South Armorican Massifs (Pyrenees, Catalonian Coastal Ranges, Menorca).

The limestone of the Genicera Fm. yielded a wealth of fossils, first mentioned by Schulz (1837), Prado \& de Verneuil (1850) and Barrois (1882) from the "griotte limestone", resp. "marbre griotte". Pelagic dwelling organisms and taxa preferring deeper-water environments predominate. These are goniatites, cyathaxonid corals, trilobites characteristic of the Kulm facies, and conodonts; opposed brachiopods are scarce (see review in Sánchez de Posada et al., 1996). Later contributions added to the knowledge of bivalves (Amler \& Winkler Prins, 1999) and agglutinating foraminifers (Balthasar \& Amler, 2003; Herbig et al., 2011).

Macroscopic remains of echinoderms are exceedingly rare within the formation, although articulated pelmatozoan stem ossicles occur in places, and disarticulated remains are quite common in thin sections. Herbig $(1982,1994)$ described an at least in part autochthonous monospecific crinoid fauna with Balearocrinus cantabricus Herbig, 1982, a genus, which is also known from time-equivalent deepwater deposits of Menorca (Bourrouilh \& Termier, 1973) and the Bechar Basin of Algeria (Webster et al., 2004). A further crinoid cup from the Genicera Fm. of northern León was described by Breimer (1962, not figured); Rhabdocrinus scotocarbonarius from contemporaneous cephalopod limestones of the Palentine realm (Morris, 1992) belongs to Balearocrinus cantabricus (Herbig, 1994).

Zamora (2016) reviewed the Palaeozoic echinoderms from northern Spain and listed the few isolated Carboniferous finds. Except from crinoids, descriptions of Pennsylvanian blastoids (Sieverts-Doreck, 1951; Joysey \& Breimer, 1963), asterozoans and echinoids (Bless \& Sánchez de Posada, 1971) exist. Bless \& Sánchez de Posada (1971) also mentioned holothurian ossicles without further specification. First short accounts on the present fauna were published by Pabst \& Herbig (2018, 2019). Herein, we document these first mainly non-crinoid echinoderm remains from the Genicera Fm., namely disarticulated holothurian, ophiuroid, ophiocistioid and stenuroid ossicles as well as other indeterminate echinoderm ossicles in detail. It has to be stressed that these are the first reports of ophiocistioids, of apodid holothurians, of some "arcaic ophiuroids" (Furcaster among Oegophiuroidea, Stenuroidea) and of microcrinoids (allagecrinids) from the Palaeozoic of Spain. Apart 
from two Upper Devonian occurrences of actinopodian holothurians (?Microantyx Kornicker \& Imbrie, 1958 and one eucaudinid) described by García-López \& Truyols (1974), no taxonomical study on holothuroid ossicles from the Palaeozoic of Spain exists at all.

All ossicles have been derived from three sections in northern León during an ongoing study linking carbonate microfacies and agglutinating foraminifers.

\section{GEOLOGICALAND STRATIGRAPHICAL SETTING}

The studied sections Millaró, Olleros de Alba and Rabanal de Fenar belong to the Asturo-Leonese facies realm. They are situated in the Sobia-Bodón and Somiedo-Corecilla units, which are two of the typical thin-skinned nappe structures constituting the Cantabrian Mountains (Julivert, 1971; Pérez-Estaún et al., 1988) (Fig. 1). Detailed studies of the Millaró section are from García-López \& SanzLópez (2002) and Sanz-López et al. (2007). Previous data from Olleros de Alba were summarized and supplemented by García-López \& Sanz-López (2002), including the ammonoid and trilobite findings of Higgins et al. (1964) and Gandl (1977). The section north of Rabanal de Fenar, southeastern Alba Syncline, hitherto remained unstudied. A near-by section is noteworthy due to an important, local debrisflow deposit at the top of the Genicera Fm. reworking limestone clasts of the San Adrián Mb. (Keller et al., 2008).

In the type locality of the Genicera Fm. Wagner et al. (1971) distinguished three members, from below Gorgera $\mathrm{Mb}$. (cephalopod limestone), Lavandera $\mathrm{Mb}$. (shales and cherts) and Canalón Mb. (cephalopod limestone). However, this subdivision varies considerably in the Asturo-Leonese facies realm, as exemplified by sections in the wider surroundings of the Bernesga Valley. In the southernmost outcrops, up to $20 \mathrm{~m}$ red and green shale and marl appear in the uppermost Genicera Fm. (Olaja Beds, Wagner et al., 1971). Further north, dark grey micritic limestone occur in many sections above the Canalón Mb. (San Adrián Mb., Reuther, 1977; Kullmann et al., 1977), once more overlain by a thin cephalopod limestone package (Millaró Beds, Sanz-López et al., 2004) (Fig. 2). Like previous authors, we include the San Adrián Mb. and the overlying Millaró Beds into the uppermost Genicera Fm., contrary to Nemyrovska et al. (2011), who proposed that both form the base of the overlying Barcaliente Fm. (Wagner et al.,

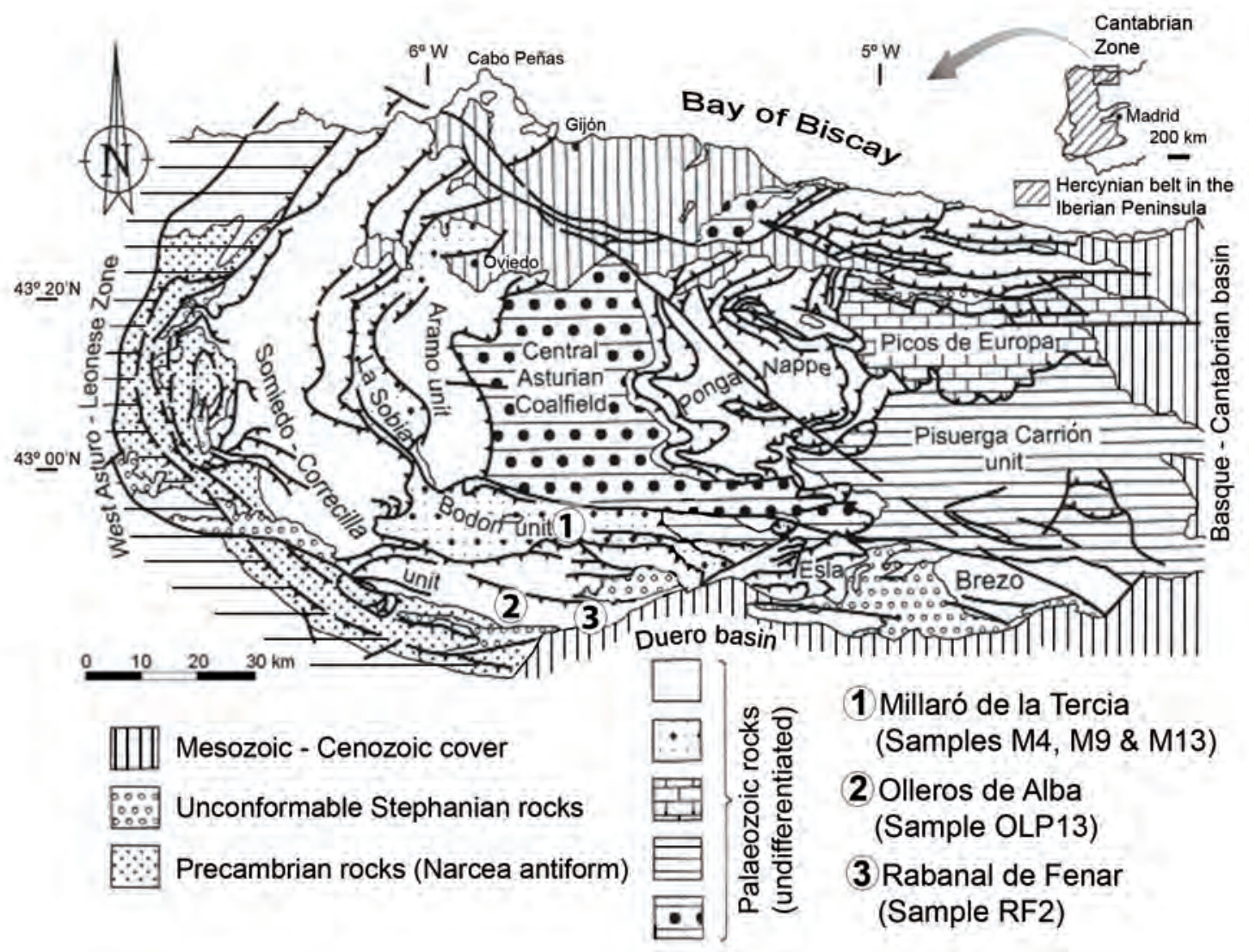

Figure 1. Modified geological map of the Cantabrian Zone according to Julivert (1971) and Pérez-Estaún (1988) with the localization of the samples that provided remains of echinoderms. 


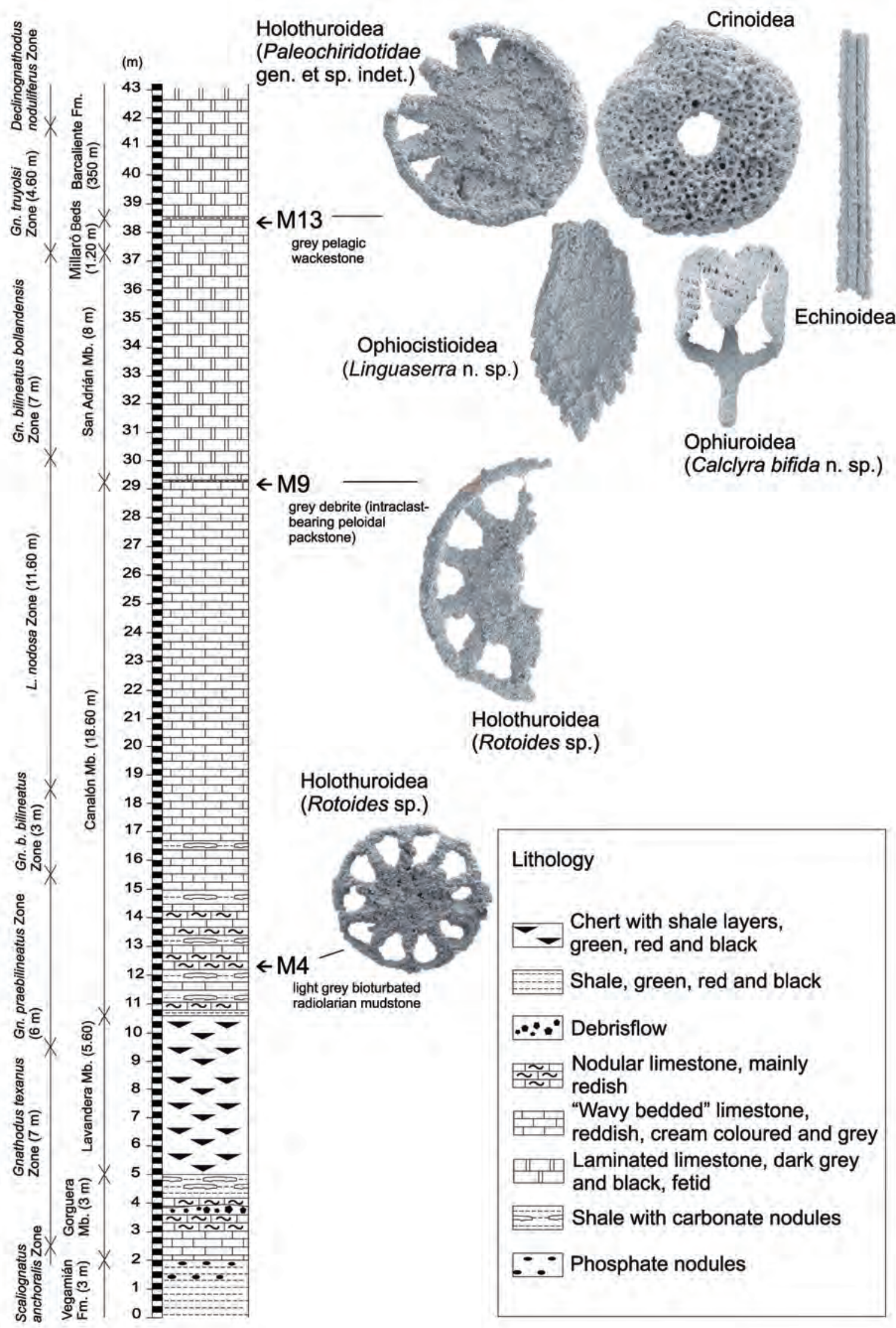

Figure 2. Section of the Genicera Fm. at Millaró de la Tercia (Province León) with the samples that provided echinoderm remains specifying their contents. Conodont zones from García-López \& Sanz-López (2002) and Sanz-López et al. (2007). 
1971). Elsewhere, like in the studied section Olleros de Alba, the siliceous Lavandera $\mathrm{Mb}$. is completely missing, and, like in the locality of Rabanal de Fenar, conspicuous debris flow sediments, however consisting of reworked nodular and cephalopod limestone might be intercalated in the Canalón Mb.

The differentiated development of the uppermost Genicera Fm. in northern León reflects the different segments of a vanishing, south-dipping pelagic carbonate ramp (Sanz-López et al., 2004). The shales of the Olaja Beds represent the deepest, most distal part of the ramp, where the first flysch of the Cantabrian Zone from the Variscan orogen front prograding from the South (Kullmann \& Schönenberg, 1975) were deposited. The dark grey carbonates of the San Adrián Mb. correspond to the opposite, more proximal part of the ramp, receiving gravitationally redeposited, probably mostly calciturbiditic material from the foreland carbonate platform. Debrisflow sediments indicate tectonic ruptures or steepening of the ramp.

\section{LITHOLOGY AND CARBONATE MICROFACIES}

The predominantly calcareous upper Genicera Fm. (Canalón Mb. to Millaró Beds) in the studied sections consists mostly of light-grey, pinkish and cream-coloured, well-bedded to wavy bedded cephalopod limestone and subordinate red nodular and flaser bedded limestone. Beds are often separated by centimetric shale interbeds. Thinbedded platy limestone and layers of limestone nodules in argillaceous matrix occur rarely. Locally, debrisflow sediments consisting of redeposited nodular limestone occur. Besides, characteristic dark micritic limestone constitutes the San Adrián Mb.

All studied samples are cephalopod limestones from the upper and uppermost part of the Genicera Fm. (Table 1). Most of the predominant mudstones and the less frequent, mostly sparsely packed wackestones are homogenized due to bioturbation (Figs 3b, 3d, 3g, 3m). They show stirred up bioclasts (Fig. 3e) as well as defined burrows (Figs 3f, 3m).

Relicts of primary bedding occur. These are distinct laminae, e.g. of enriched, coarser grained bioclasts, indicating episodic influx of material prior to bioturbation (Fig. 3b). Some bioclasts might be encrusted by ferruginous microstromatolites (Fig. 3d). Also distinct, in cases ferromanganese encrusted discontinuity surfaces occur in different microfacies. In mudstones scattered remains of planktonic organisms like radiolaria, globochaetes, ultrathin-shelled ostracodes and larval molluscs (goniatites, bivalves and/or brachiopods) predominate. Rare benthic elements might occur. In sample M9, section Millaró, such a microfacies is reworked in a debrisflow facies, as indicated by its completely heterogenic texture. It is characterized by a pelletized matrix, i.e. very small intraclasts of reworked mud, by scattered intraclasts up to $10 \mathrm{~mm}$ in diameter and by exceedingly large bioclasts, in cases with rotated geopetal structures (Figs 3a, 3k). Sample M4, section Millaró, reveals a bioturbated, pure radiolaria mudstone from the very distal, deep ramp (Fig. $3 \mathrm{~m})$. Also a packstone mainly composed of globochaetes (Figs 3d, 3h, 3j, sample OLP13, section Olleros de Alba), indicates basinal environments (Vachard et al., 1994). In the less frequent wackestones, which casually might grade into packstones, remains of benthonic invertebrates are more common. They comprise fragments of echinoderms (Figs $3 \mathrm{~h}-\mathrm{i}$ ), thick-shelled adult gastropods, bivalves and brachiopods, thick-shelled ostracodes, as well as rare trilobites (Fig. 3j) and bryozoans (Sample M13, section Millaró).

Distinct is a microbialite microfacies (Figs 3c, 31, sample RF2, section Rabanal de Fenar), already noted from the Genicera Fm. by Mamet \& Boulvain (1991) and Balthasar \& Amler (2003). It consists of a meshwork of clotted peloids and irregular spar-filled fenestrae that are partly floored with peloidal internal sediment. Bioclasts are missing except for scattered radiolarians and thin-shelled ostracodes. However, agglutinating foraminifers from the Reophax biofacies in the microbialite facies indicate a basinal, oxygen-deficient environment (Gutschick \& Sandberg, 1983; Sandberg \& Gutschick, 1984; Herbig et al., 2011).

Macrofacies and microfacies indicate the wellknown general pelagic environment of the Genicera Fm., but surprisingly a more detailed facies model does not exist except for the studies of Eichmüller \& Seibert (1984) and Seibert (1986). Discontinuity surfaces and associated intraclasts result mostly from halmyrolitic processes. They indicate condensation, omission and might result in cryptohardgrounds. The mudstones with predominantly planktic organisms are from true basinal environments. However, globochaete-bearing packstones prove redeposition within the deep basin by pelagic turbidites and, hence the existence of a seafloor topography. Also the gravitatively redeposited debrisflow facies documents intrabasinal slopes or scarps. Microbialites are related to the deep oxygen-deficient basin. Only the wackestone facies with higher diversity and abundance of predominantly benthic faunal elements indicates somewhat shallower, but persisting pelagic environments.

Concerning the echinoderms, apart from quite abundant columnals and brachials of crinoids, only some transverse sections of echinoid spines were determinable. Further indeterminable echinoderm plates are present, but from the taxon groups described herein not a single element could be reliably identified in the thin-sections. 


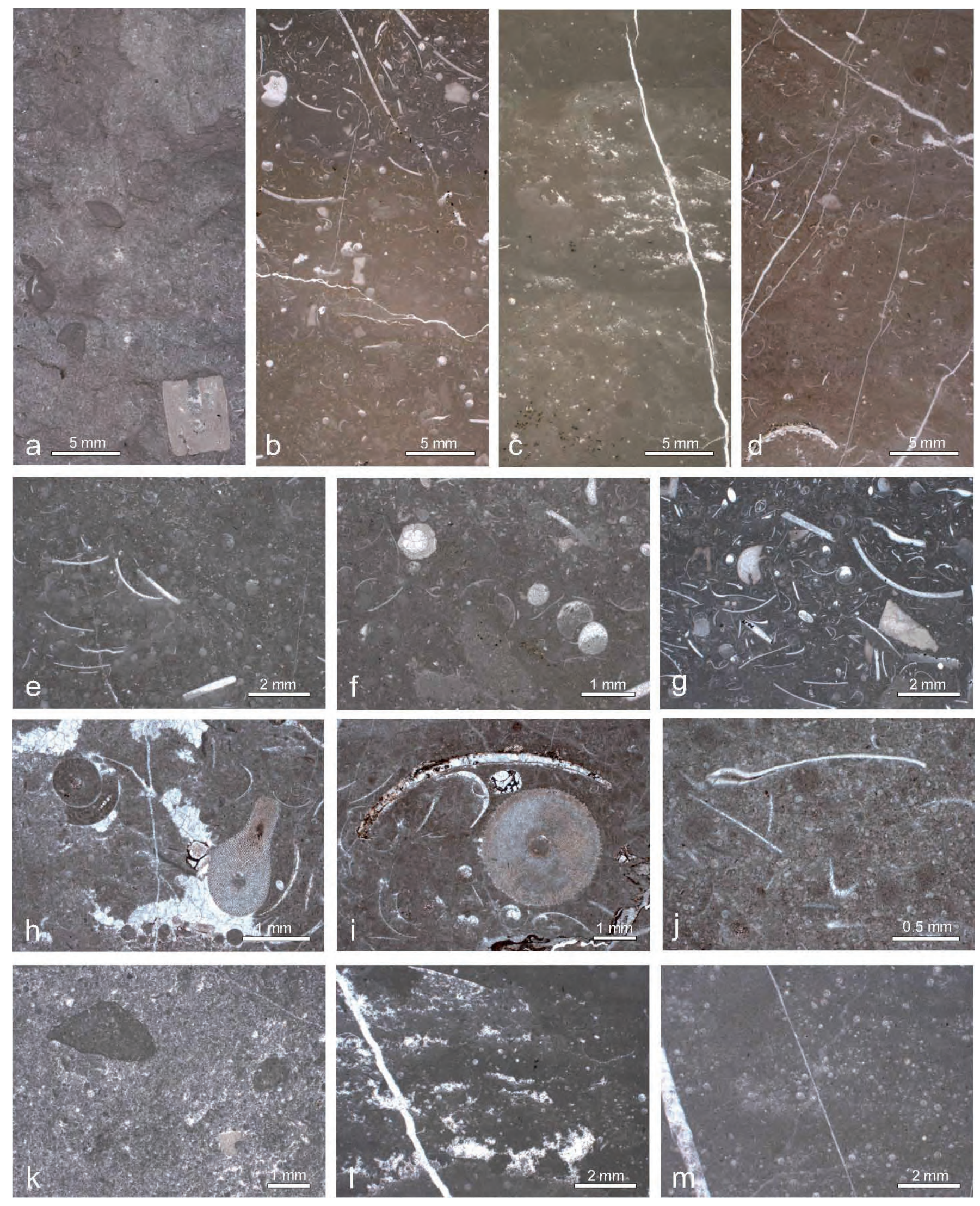


Table 1. Geographic and lithostratigraphic position of the echinoderm-ossicle bearing samples and carbonate microfacies.

\begin{tabular}{|c|c|c|c|c|c|}
\hline Sample & $\begin{array}{c}\text { Section } \\
\text { Coordinates }\end{array}$ & $\begin{array}{c}\text { Tectono-stratigraphic } \\
\text { Unit }\end{array}$ & Stratigraphy & $\begin{array}{c}\text { Conodont zone } \\
\text { (chronostratigraphy after } \\
\text { Sanz-López et al., 2007) }\end{array}$ & Microfacies \\
\hline M13 & $\begin{array}{l}\text { Millaró de la Tercia } \\
42^{\circ} 58^{\prime} 40^{\prime \prime} \mathrm{N} \\
5^{\circ} 38^{\prime} 54^{\prime \prime} \mathrm{W}\end{array}$ & Bodón Unit & $\begin{array}{l}\text { Millaró Beds; } \\
\text { uppermost bed } \\
\text { (= uppermost bed of } \\
\text { Genicera Fm.) }\end{array}$ & $\begin{array}{l}\text { Gnathodus truyolsi } \\
\text { Zone } \\
\text { late Serpukhovian } \\
\text { (middle/late } \\
\text { Arnsbergian) }\end{array}$ & $\begin{array}{l}\text { pelagic } \\
\text { wackestone }\end{array}$ \\
\hline RF2 & $\begin{array}{l}\text { Rabanal de Fenar } \\
42^{\circ} 49^{\prime} 12^{\prime \prime} \mathrm{N} \\
5^{\circ} 34^{\prime} 35^{\prime \prime} \mathrm{W}\end{array}$ & $\begin{array}{l}\text { Somiedo-Correcilla } \\
\text { Unit }\end{array}$ & $\begin{array}{l}\text { Transition Olaja Beds/ } \\
\text { Millaró Beds; } \\
\text { lowermost bed } \\
\text { overlaying } \\
\text { San Adrián } \mathrm{Mb} \text {. }\end{array}$ & $\begin{array}{l}\text { Gn. bilineatus } \\
\text { bollandensis Zone } \\
\text { Serpukhovian (early } \\
\text { Arnsbergian) }\end{array}$ & microbialite \\
\hline M9 & $\begin{array}{l}\text { Millaró de la Tercia } \\
42^{\circ} 58^{\prime} 40^{\prime \prime} \mathrm{N} \\
5^{\circ} 38^{\prime} 544^{\prime \prime} \mathrm{W}\end{array}$ & Bodón Unit & $\begin{array}{l}\text { Canalón Mb, uppermost } \\
\text { bed below San Adrián } \\
\mathrm{Mb} \text {. }\end{array}$ & $\begin{array}{l}\text { Lochriea nodosa Zone } \\
\text { uppermost Viséan } \\
\text { (Brigantian)/early } \\
\text { Serpukhovian } \\
\text { (Pendleian) }\end{array}$ & $\begin{array}{l}\text { debrite } \\
\text { (intraclast- } \\
\text { bearing peloidal } \\
\text { packstone) }\end{array}$ \\
\hline OLP13 & $\begin{array}{l}\text { Olleros de Alba } \\
42^{\circ} 48^{\prime} 12^{\prime \prime} \mathrm{N} \\
5^{\circ} 411^{\prime} 58^{\prime \prime} \mathrm{W}\end{array}$ & $\begin{array}{l}\text { Somiedo-Correcilla } \\
\text { Unit }\end{array}$ & Lower Canalón Mb. & $\begin{array}{l}\text { Gn. bilineatus } \\
\text { bilineatus Zone } \\
\text { late Viséan }\end{array}$ & $\begin{array}{l}\text { globochaete } \\
\text { wackestone to } \\
\text { packstone }\end{array}$ \\
\hline M4 & $\begin{array}{l}\text { Millaró de la Tercia } \\
42^{\circ} 58^{\prime} 40^{\prime \prime} \mathrm{N} \\
5^{\circ} 38^{\prime} 544^{\prime \prime} \mathrm{W}\end{array}$ & Bodón Unit & $\begin{array}{l}\text { Lowermost Canalón } \\
\mathrm{Mb} \text {. }\end{array}$ & $\begin{array}{l}\text { Gn. praebilineatus } \\
\text { Zone } \\
\text { late Viséan }\end{array}$ & $\begin{array}{l}\text { bioturbated } \\
\text { radiolaria } \\
\text { mudstone }\end{array}$ \\
\hline
\end{tabular}

Figure 3. Carbonate microfacies of the echinoderm ossicles bearing samples from the upper Genicera Fm. in overview (a-d) and detail (e-m). (a, k) Debrisflow sediment consisting of bioturbated peloidal packstone with scattered dark intraclasts. (k) Detail showing dark intraclasts floating in the pelletized matrix. Millaró de la Tercia, uppermost bed of Canalón Mb. Sample M9 (GIK 1411-M9). (b, e-g) Grey, bioturbated pelagic wackestone with diverse organisms showing relictic bedding. Predominating microbioclasts and radiolarians in a strongly burrowed micritic matrix in the lower part are overlain by a bioclast-rich part with strongly fragmented shells (brachiopods and/or bivalves), goniatites, crinoid ossicles, larval shells ("filaments") and undeterminable microbioclasts. (e) Detail from the lower part with abundant radiolarian ghosts filled by micritic cement, which is also seen as geopetal infill in scarce shells. Note stacking of shells by bioturbation. (f) Detail from the lower part showing well-preserved echinoderm ossicle of unknown affinity and embryonic ammonoid in strongly bioturbated micritic matrix. (g) Detail from the upper part with abundant bioclasts, fragmented and texturally homogenized due to bioturbation. Millaró de la Tercia. Uppermost bed of the Millaró Beds (= uppermost bed of the Genicera Fm.). Sample M13 (GIK 1411-M13). (c, l) Light grey, radiolarians and planktonic ostracodes bearing microbialite. The lack of benthic biota appears to be well correlated with the basinal, oxygen depleted Reophax biofacies of the insoluble residue. (l) Detail showing sparitic fenestrae within clotted peloidal micrite. Lowermost bed of a nearly 3 m thick succession of intercalated red and green shales and cephalopod limestone below the base of the Barcaliente Fm., probably an equivalent of the Millaró Beds. Rabanal de Fenar. Sample RF2 (GIK 1411-RF2). (d, h-j) Red globochaete wackestone/packstone including other planktic biota like embryonic goniatites, ultra-thin shelled ostracodes, filaments and common radiolarians, the latter only seen as micritic "shadows" and barely discernible from the matrix. Few larger shells, trilobite and crinoid fragments redeposited from shallower environment. Note bored and ferromanganese encrusted shell at lower left. (h) Detail of a burrow fill with some micrite-filled radiolarians ghosts at its floor, well-preserved echinoderm ossicle, and uniserial globochaete colony within embryonic ammonoid. (j) Detail with well-preserved crinoid columnal. j: detail showing the general appearance of the globochaete-rich matrix and trilobite fragment. Olleros de Alba, lower Canalón Mb. Sample OLP13 (GIK 1411-OLP13). (m) Bioturbated radiolarian mudstone; additional biota missing. Millaró de la Tercia, lowermost Canalón Mb. Sample M4 (GIK 1411-M4). 


\section{METHODS AND MATERIALS}

The herein presented echinoderm ossicles were a casual find of a research on arenaceous foraminifers. They have been derived from limestone processed with low concentrated acetic acid (8-10\%) for three to four days. Hence, they were only obtained from the size fraction $0.1-0.2 \mathrm{~mm}$ and $0.2-0.63 \mathrm{~mm}$, being aware that concerning echinoderm ossicles a study of coarser fractions up to at least $5 \mathrm{~mm}$ is pendent. Microfossils of the residues were, in descending order, agglutinating foraminifers, conodonts, radiolarians, few ichthyolites and hexactinellid sponge spicules, and, most rarely, not silicified echinoderm ossicles. Due to their calcareous nature, echinoderm remains are normally missing or are very rare and poorly preserved after acid treatment. However, their high-Mg calcite skeleton is transformed early in diagenesis into the chemophysical stable low-Mg calcite; moreover, the monocrystalline nature of the ossicles is largely preserved (e.g. Smith, 1990; Ausich, 2001). Both increase the resistance to acid digestion, especially within a fine-grained calcareous matrix (Zank1, 1966). A low content of argillaceous material also seems to favour a selective dissolution (Mostler, 1968a), although Boczarowski (2001) denoted that the protective function of clay particles covering the ossicles in the residue might also be considered. Anyhow, an accurately timed interruption of digestion and the very fine-grained, pure carbonate rock constituting our samples appears to be crucial for preservation of the herein presented microfauna.

The richest echinoderm fauna, including the most spectacular ossicles, were obtained from fraction $0.1-0.2$ mm of sample M13, uppermost bed of the Genicera Fm. (Millaró Beds), section Millaró (Fig. 2). This fauna, albeit mostly only fragmentary and strongly corroded, comprises approximately $25 \%$ of all microfossils of the mentioned fraction: $300 \mathrm{~g}$ of digested limestone provided all together about 1450 microfossils, this means about 360 echinoderm ossicles. The other productive samples provided about 30 echinoderm ossicles from comparable sample weights.

\section{THE ECHINODERM OSSICLES}

The recovered ossicles reveal a differentiated fauna comprising "arcaic ophiuroids", holothurians, ophiocistioids, echinoids and crinoids. About $40 \%$ of the ossicles were poorly preserved or not determinable. The remaining specimens could be assigned approximately half to holothurians, tentatively including all wheel-shaped ossicles and the majority of the sieve plates, and half to "arcaic ophiuroids". Few were identified as remains of ophiocistioids, echinoids and crinoids.
Two Palaeozoic "arcaic ophiuroid" ossicle sets are recognizable. First, distinctive elements of the Calclyridae Frizzell \& Exline, 1956 (= perforated ophiuroid spines) (Figs $4 \mathrm{a}-\mathrm{c}$ ) and co-occurring skeletal elements resemble assemblages reported by Boczarowski (2001) from the Middle Devonian of Poland that were attributed to the genus Furcaster Stürtz, 1886, order Oegophiurida Matsumoto, 1915. The co-occurring elements comprise vertebrae composed of two halves loosely fused along a suture (Figs $4 \mathrm{e}-\mathrm{f}$ ), various kinds of spines (Figs $4 \mathrm{~g}-\mathrm{i}$ ) and possible lateral arm plates (Figs $7 \mathrm{k}-\mathrm{m}$ ). Mostler (1971a) described a similar fauna with Calclyra from the Mississippian of Afghanistan. Further Calclyra species were reported from the late Permian of Central Germany (Frizzell \& Exline, 1956), SW USA (Wernlund, 1977) and Sicily/Italy (Kozur \& Mostler, 1989). The Oegophiuroida are regarded as Palaeozoic ophiuroids (O'Hara et al., 2017).

Second, a characteristic lateral arm plate of the genus Pectenura Haude, 1982 was found (Fig. 4d). Boczarowski (2001) still attributed the genus to the ophiuroid order Stenurida Spencer, 1951, but Blake (2013) supposed the stenurids to constitute a separate monophyletic Palaeozoic echinoderm class Stenuroidea. However, paraphyly of the class was not excluded by Blake (2013) and assumed by O'Hara et al. (2017). Recently, Hunter \& McNamara (2018) regarded both the Oegophiurida and the Stenuroidea as the "arcaic" stem group of ophiuroids. In both taxa the ambulacrals are not firmly fused to form vertebrae like in the crown group of extant ophiuroids and their Palaeozoic representants ("modern" ophiuroids). Anyhow, further morphological features place the oegophiuroids much closer to the "modern" ophiuroids (e.g. basins of tube feet restricted to single ambulacrals, lateral arm plates articulate directly with ambulacrals).

Among the holothurians both stem groups are identified. Apodida Brandt, 1835 are characterized by the absence of tube feet and distinctive "apodid wheel-shaped" ossicles (Fig. 6) (e.g. Ludwig, 1889-1892; Gilliland, 1993; Smirnov, 1998). Contrary, Actinopoda Ludwig, 1891 possess tube feet and differentiated ossicles (Figs 5, 7n-o). Our assignment to the latter is not always unequivocal, as same morphotypes occur in different echinoderm classes and even in phylae outside of echinoderms. This is the case of branched ossicles (Figs 5h-m) that might be compared with the Palelpidia/Praeeuphronides group of the Elasipodida Théel, 1882 (Gilliland, 1993). Also the assignment of sieve plates (Figs 5a-e) is equivocal in spite of the strong similarity of at least the Eocaudina septaforaminalis group to sieve plates of modern Dendrochirotida Grube, 1840 (Pawson, 1966, Gilliland, 1993).

Contrary, according to Miller et al. (2017), fourpillared table plates (Figs $5 \mathrm{f}-\mathrm{g}$ ) like other table plates are distinctive for the clade Pneumonophora Brandt, 1835 sensu Selenka, 1867 within the Actinopoda. According to 
Gilliland (1993), the same is true for anal teeth (Figs 7n-o). Pneumonophora is the sister clade of the Elasipodida sensu Miller et al., 2017 and comprises all the remaining Actinopoda. However, as noted by Miller et al. (2017), the assignments of fossil holothuroid ossicles to existing crown clades may need reassessment.

Ophiocistioids are unequivocally represented by extremely rare, but morphologically differing goniodonts (Figs 7a-d) of the Liguaserridae Reich \& Haude, 2004.

Crinoid ossicles (columnals and calyx plates, Figs $4 \mathrm{~m}-\mathrm{o}, 7 \mathrm{j}$ ) and echinoid spines (Fig. 4p) are remarkable rare in the residues, contrary to their relative abundance in thin sections. This might be due to their size, which is beyond the studied sieve fractions and/or the coarse meshed stereom structure. In fact, many of the obtained remains seem to come from micromorph forms. Figures $4 \mathrm{n}-\mathrm{o}$ represent primary peristomial cover plates ("oralia") of an allagecrinid microcrinoid. Sevastopulo (2008) shows a quite similar structure from the late Viséan of Ireland (Slievemore, County Sligo) attributed to Litocrinus (Lane \& Sevastopulo, 1981). In spite of peculiar morphologies, many echinoderm ossicles remained indeterminate (Figs $4 \mathrm{j}$, $41,5 \mathrm{i}-\mathrm{m}, 7 \mathrm{e}-\mathrm{t}$ ), due to moderate preservation.

All material is housed in the collections of the Institute of Geology and Mineralogy, University of Cologne under numbers GIK 1411 (five thin sections with corresponding numbers of the samples) and GIK 1412-1415 (four SEM stubs with echinoderm ossicles; each one defined by further suffixes). Additional material from sample M13 is kept under GIK 1416 (four microslides; suffixes 1-4) and GIK 1417 (unstudied residue, fraction $0.1-0.2 \mathrm{~mm}$ ).

Taxonomy of ophiuroids relies on Frizzell \& Exline (1956, 1966) and Boczarowski (2001); for the stenuroids on Haude (1982), Boczarowski (2001) and Blake (2013); for the holothurians on Frizzell \& Exline (1956, 1966), Gilliland (1993) and Miller et al. (2017); for the ophiocistioids on Reich \& Haude (2004), Reich \& Kutscher (2014) and Reich et al. (2018).

\section{SYSTEMATIC PALAEONTOLOGY}

Phylum ECHINODERMATA Bruguière, 1791 (ex Klein, 1754)

Subphylum ASTEROZOA von Zittel, 1895

Class OPHIUROIDEA Gray, 1840

Order Oegophiurida Matsumoto, 1915

Parafamily Calclyridae Frizzell \& Exline, 1956

Paragenus Calclyra Frizzell \& Exline, 1956

Type species Prosynapta eiseliana Spandel, 1898
[= Calclyra eiseliana (Spandel, 1898) according to Reich (2007)].

Remarks. Mostler (1971b) showed that perforated spines ("Lochstacheln") do not belong to holothurians, as assumed with doubt in the erection of Calclyra by Frizzell \& Exline (1956). They are restricted to the dorsal side of the ophiuroid disc (Mostler, 1971b) or to the proximal lateral arm plates (Boczarowski, 2001). Although Boczarowski (2001) attributed the isolated ossicles of the paragenus Calclyra to the ophiuroid genus Furcaster Stürtz, 1886, we retain Calclyra for better specific differentiation.

\section{Calclyra bifida n. sp.}

(Figs $4 \mathrm{a}-\mathrm{c}$ )

Derivatio nominis. Derived from bifidus (Latin), meaning cleft into two parts, due to the central indentation at the upper margin of the head dividing it into two equal lobes.

Holotype. The specimen GIK 1415-8 from sample M13 (Fig. 4a).

Paratype. The specimen GIK 1413-2 from sample M13 (Fig. 4c).

Additional material. Five specimens, four from sample M13 (GIK 1412-M13-16, GIK 1415-9, GIK 1413-3, GIK 1416-2) and one from sample M9 (GIK 1414-M9-1).

Type locality, type horizon and age. Quarry near the village Millaró de la Tercia, province León, Cantabrian Mountains/NW Spain (Fig. 2, Table 1). Uppermost bed of the Millaró Beds (Genicera Fm.).

Diagnosis. In front view a nearly squared head with a central indentation at its upper margin; shaft relatively long and slender.

Description. Ophiuroid spine with a characteristic basal socle, a shaft and a head. The head consists of three subparallel running rays separating two trapezoidshaped pores. The lateral rays form wings normal to the plane of the rays. They are bent inward at their rounded margins. The central ray is sharply bent at its top and fused with the lateral wings, resulting in front view in an almost squared, bilobate head with characteristic central indentation at its upper margin. The central ray finally turns obliquely outward and downward, ending as broad, triangle-shaped process. Thus two pores are formed in a basket-like structure. In cross-section the shaft is slightly oval and of irregular thickness. 


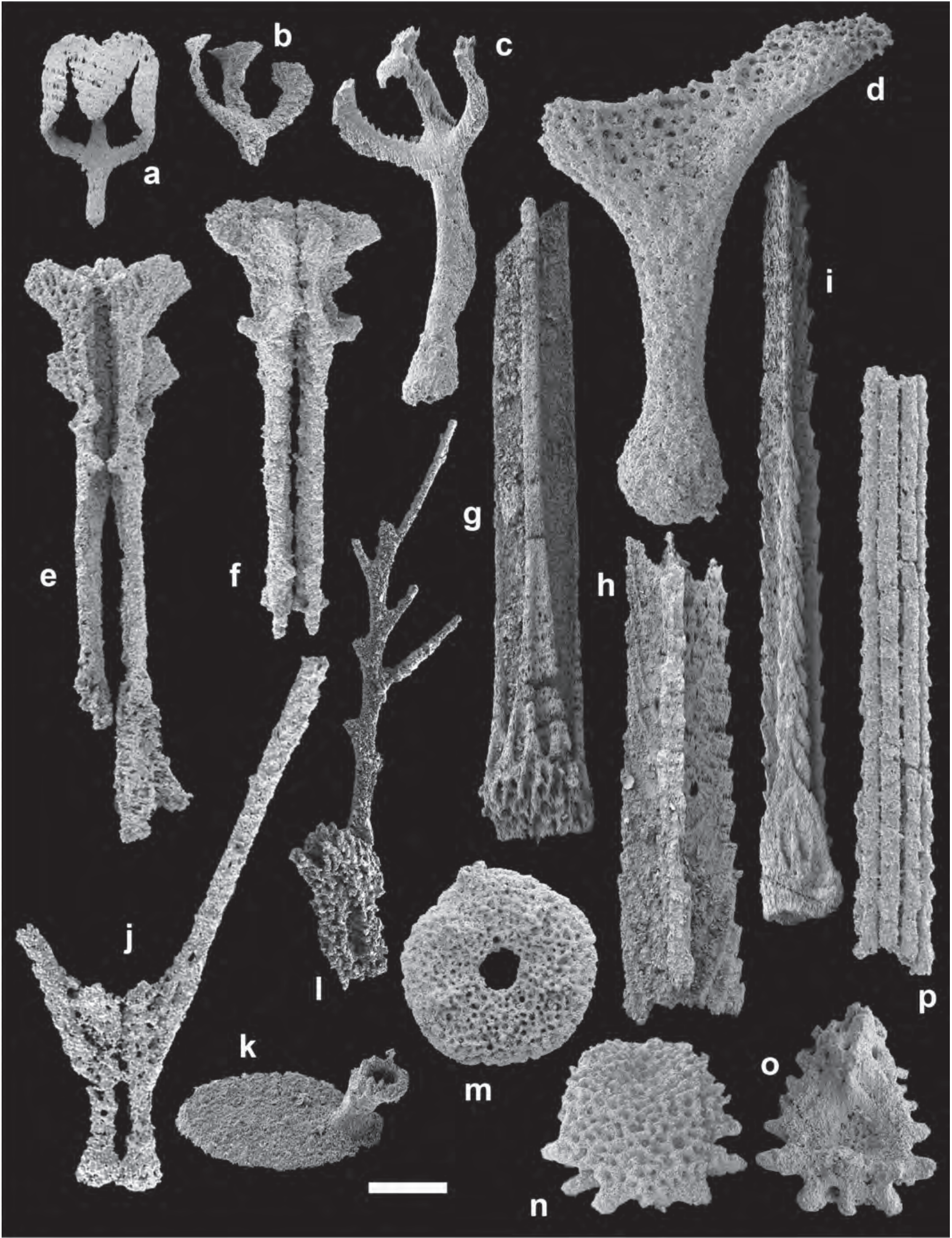


Remarks. The oval shaft of the holotype (Fig. 4a) is only partly preserved. The slightly oblique view of the paratype (Fig. 4c) shows the real morphology of the shaft. The oblique view simulates a convex run of the lateral rays, which in fact is parallel. The connection of lateral and central rays at the upper margin of the head as well as the central triangular process are not preserved in the paratype, but bending of the central ray toward the front and further downward is still perceptible.

The late Permian C. eiseliana is similar to C. bifida but the former only has a slightly concave upper margin of the head. Moreover, it differs by the stout appearance with thicker rays and shorter shaft (Frizzell \& Exline, 1956; Wernlund, 1977; Kozur \& Mostler, 1989). The head of Calclyra bifida n. sp. differs from those of the Permian $C$. gracilis Kozur \& Mostler, 1989, which are either elongate or oval to nearly subcircular, with almost rounded to blunt upper margin. C. carbonica Kozur \& Mostler, 1989, originally attributed to C. eiseliana by Mostler (1971a), occurs in stout as well as in slender morphotypes. But his haed is suboval outlined, broadest in the lower third and pointed at its upper margin. The Permian C. triangulata, C. spathulata and C. spinata, all erected by Wernlund (1977) from the Guadalupe Mountains/SW USA, just a little have cleft heads. Their names already indicate the differing shape of the heads, i.e. triangular, pointed upwards, spattle-shaped, and with a distinct distal spine. Boczarowski (2001) defined perforated forms from the Frasnian of Poland as Furcaster sp. A and compared them with $C$. eiseliana. However, according to the general shape of head and shaft, they are closer to C. spathulata Wernlund, 1977 or even C. gracilis.

Distribution. Only known from the type material, uppermost Mississippian (Serpukhovian) of the Cantabrian Mountains (NW Spain).

\section{Indeterminate ophiuroid ossicles} (Figs $4 \mathrm{e}-1$ )

Vertebrae. (Figs 4e-f) Elongate axial arm ossicles with symmetrical lateral processes (wings) for muscle attachment at the thicker, supposedly adoral quarter of the ossicles. The ventral side shows the deep radial groove that carried the axial vessel of the water vascular system (Fig. 4e), the dorsal side a more compact, protecting surface (Fig. 4f). The fused halves along a recognizable axial suture point to an attribution to the genus Furcaster (Boczarowski, 2001).

Spines. (Figs 4g-i) Long, straight ossicles with central ridge and two lateral laminae rectangular (?) projecting on each side, either completely smooth (Fig. $4 \mathrm{~g}$ ) or with serrate margin and characteristic oblique lines originating at the central ridge (Figs $4 \mathrm{~h}-\mathrm{i}$ ). The ridge might be characteristically braided (Fig. 4i). The extended base of the ossicles displays rapidly converging, additional longitudinal ridges. Analogous spines were reported e.g. by Boczarowski (2001) form the Devonian of Poland and attributed to the genus Furcaster.

?Ophiuroid ossicle. (Fig. 4j) The distinctive element is a not completely fused, bilateral symmetrical ossicle. Each half has one knob-like end, followed by a narrow rounded shaft widening above and proceeding into two long spines that project at an angle of about $30^{\circ}$ from the axis of the ossicle. The symmetrical shape of the element is reminiscent of a vertebra, but we are not aware of such long-spined types.

Marginal ossicles of the central disc. (Fig. 4k) A single minute skeletal element with an oval, imperforated base and an eccentrically tiny smooth vertical process; the process has a conical depression or hollow ending with irregular to zigzagged margin. Analogous elements were described by Boczarowski (2001) from the Middle and Upper Devonian of the Holy Cross Mountains/Poland and attributed to ossicles located within the dermis protecting the aboral side of the central disc.

?Ophiuroid spine. (Fig. 4l) A coarse meshed stereomal basal socle (?) with one branched "spine", roundish in cross section. The "spine" consists of a straight main rod with right and left alternating, oblique upwards projected secondary rods (mostly broken). Boczarowski (2001) described similar structures from the Middle Devonian (early Givetian) of the Holy Cross Mountains/Poland as "ophiuroid or crinoid spines (?)".

Figure 4. Ophiuroids, crinoids and echinoids. All from sample M13, except specimen $\mathbf{k}$, which is from sample OLP13. a-c) Calclyra bifida n. sp. (a) Holotype (GIK1415-8), front view. (b) Poorly preserved fragment (GIK1413-3), oblique view. (c) Paratype (GIK1413-2), oblique view. (d) Lateral arm plate of Pectenura sp. (GIK1413-04). e-f) Ophiuroid arm vertebrae. e: oral view (GIK1413-9). (f) Aboral view (GIK1413-8). g-i) Ophiuroid spines. (g) Fragment with preserved basal socle (GIK1413-14). (h) Fragment with serrate laminae (GIK1412-M13-10). (i) Nearly complete specimen with braided ridge (GIK1415-23). j) ?Ophiuroid element (GIK1412-OLP13-3). k) Ophiuroid marginal ossicle of the central disk (GIK1413-V2). l) Ophiuroid or crinoid spine (GIK1415-24). m-o) Crinoid ossicles. (m) columnal (GIK1413-06). (n-o) Primary peristomial cover plates ("oralia") of an allagecrinid microcrinoid. (n) External view (GIK1415-10). (o) Internal view (GIK1415-11). p) Echinoid spine (GIK1413-10). Scale bar $=0.1 \mathrm{~mm}$. 
Class STENUROIDEA Blake, 2013

Order Stenurida Spencer, 1951

Genus Pectenura Haude, 1982

Type species Pectenura horni Haude, 1982

\section{Pectenura sp.}

(Fig. 4d)

Material. 1 specimen, sample M13 (GIK1413-04).

Description. Bone-shaped lateral arm plate. One end terminating in a club-shaped expansion. Opposite to the relatively long shaft the convexly bent end develops into two branches of different length. Faint grooves run from the club along the shaft into the coarse-meshed branches. The convex, branched end of the lateral arm plate is thought to wrap a vertebra.

Remarks. Very similar lateral arm plates were described by Boczarowski (2001) and attributed to Pectenura, which is based on completely preserved ophiuroids reported by Haude (1982) from lowermost Namurian (Serpukhovian) black shales of the Rhenish Mountains, Germany. Especially close seems to be $P$. hamata Boczarowski, 2001 from the early Givetian of the Holy Cross Mountains, Poland.

Distribution. Isolated ossicles of Pectenura were described from the Middle Devonian and early Upper Devonian of the Holy Cross Mountains (Poland, Boczarowski, 2001) and from the Upper Mississippian (Serpukhovian) of the Cantabrian Mountains (NW Spain; herein). Haude (1982) described complete specimens from the lowermost Namurian (Serpukhovian) of the Rhenish Mountains (Germany).

Subphylum ECHINOZOA von Zittel, 1895

Class HOLOTHUROIDEA de Blainville, 1834

(without rank) ACTINOPODA Ludwig, 1891

Parafamily Calclamnidae Frizzell \& Exline, 1956 [pars]

Genus Eocaudina Martin, 1952 emend. Gutschick \& Canis, 1971

Type species Eocaudina septaforaminalis Martin, 1952 emend. Gutschick \& Canis, 1971

Eocaudina mccormacki Frizzell \& Exline, 1956

(Fig. 5a)
1881 Ancistrum? sp.; Etheridge, p. 5, fig. 4.

1932 Ancistrum? sp.; Croneis \& McCormack, p. 142, pl. 18, fig. 29, pl. 20, figs 29, 38.

*1956 Eocaudina mccormacki sp. nov.; Frizzell \& Exline, p. 87-88, pl. 3, fig. 9.

1971 Eocaudina mccormacki Frizzell \& Exline; Gutschick \& Canis, p. 334, pl. 47, figs 26, 28, pl. 48, figs 17-30.

1973 Eocaudina mccormacki Frizzell \& Exline, 1955 [sic!]; Matyja et al., p. 139, pl. 1, figs 3-10, 16, 21, 23, pl. 2, figs 5, 16-17 [cum syn.].

1976 Eocaudina mccormacki Frizzell \& Exline; Kozur et al., p. 12.

1977 Eocaudina mccormacki Frizzell \& Exline, 1955 [sic!]; Wernlund, p. 52-53, pl. 1, figs 27-29.

1983 Thuroholia mccormacki (Frizzel \& Exline) [sic!]; Zhang, p. 333, pl. 1, 1-5.

1984b Eocaudina gutschicki Frizzell \& Exline; Kozur, p. 63, pl. 3, 4 [only].

1985 Thuroholia mccormacki Frizzell \& Exline; Zhang, p. 29, pl. 1, 8-9.

?1985 Eocaudina mccormacki Frizzell \& Exline, 1955 [sic!]; Ding, p. 341-342, pl. 1, figs 2-6, 8-9, 17, pl. 3, figs 1-2.

1991 Eocaudina mccormacki Frizzell \& Exline; Langer, p. 44-45, pl. 7, figs $1,4,7$, pl. 8, fig. 5 .

1993 Eocaudina mccormacki Frizzell \& Exline; Etheridge (1881) fide Gilliland, pl. 11, fig. 3.

?1993 Eocaudina mccormacki Frizzell \& Exline; Zhang, p. 107, pl. 1, fig. 27.

non 2003 Eocandina mccormacki Frizzel \& Exline [sic!] (= E. gutschicki vel. E. septaforaminalis); Aboussalam, pl. 23, fig. 17.

2013 499. mccormacki Frizzell \& Exline, 1956; Eocaudina; Reich, p. 42.

Material. 35, partly doubtful assigned specimens, all from sample M13. 12 specimens catalogued (GIK 141326, GIK 1413L, GIK 1413-31, GIK 1415e, GIK 1415f, GIK 1415j, GIK 1415L, GIK 1415n, 1 specimen in GIK 1416-3, 3 specimens in GIK 1416-4).

Description. Slightly concavo-convex subcircular to subpolygonal sieve plates with thickened outer margin; more or less equal-sized pores, relatively numerous $(>50)$ and small, subpolygonal shaped or, if poorly formed, circular to irregular; lattices relatively thin. 
Remarks. Due to their great variability, Eocaudina species can be very close to each other and even overlap morphologically (Boczarowski, 2001). We try to exclude at least some clearly distinct species. E. marginata (Langenheim \& Epis, 1957) differs by its larger central pores surrounded by smaller marginal ones. The often somewhat elongated E. croneisi Frizzell \& Exline, 1956 has clearly circular pores and an irregular outer margin. Our forms also miss the characteristic enlarged rim of E. columcanthus Gutschick et al., 1967. E. gutschicki Frizzell \& Exline, 1956 has fewer pores (see Matyja et al., 1973) resembling partly small E. septaforaminalis with its characteristic, clearly discernible four central pores surrounded by one or more cycles of secondary pores. $E$. subhexagona Gutschick et al., 1967 has distinct hexagonal pores and could be stronger concavo-convex; E. plaga Boczarowski, 2001 is completely flat, irregular shaped, and has unaligned pores separated by relatively thick lattices or trabeculae. E. ovalis Matyja et al., 1973 has elliptical or elongate outline and more densely distributed pores; $E$. gornensis Matyja et al., 1973 is only a hexagonal variety according to Boczarowski, 2001. Other close species are E. septaforaminalis, E. rimosa Boczarowski, 2001 or even the Mesozoic E. mortenseni Frizzell \& Exline, 1956. Similarities and overlapping morphologies led to the reinterpretations of many forms originally defined as E. mccormacki. Thus, Matyja et al. (1973) excluded many specimens of E. mccormacki originally figured by Gutschick \& Canis (1971) and later Boczarowski (2001) reinterpreted all these as E. septaforaminalis, likewise E. mccormacki from Langer (1991). Additionally, he reinterpreted nearly all E. mccormacki retained by Matyja et al. (1973) as E. septaforaminalis, E. ovalis or E. plaga. In our opinion some Carboniferous specimens of Ding (1985) and Zhang (1993) and the Middle Devonian specimen of Aboussalam (2003) also need revision. Already Wernlund (1977) supposed that many species of Eocaudina actually are synonyms of E. septaforaminalis.

Distribution. E. mccormacki is described from the Devonian and Carboniferous of the United States (Croneis \& McCormack, 1932; Summerson \& Campbell, 1958; Gutschick, 1959; Gutschick et al., 1967; Gutschick \& Canis, 1971), the Devonian of Poland (Matyja et al., 1973) and France (Aboussalam, 2003), the Carboniferous of Scotland (Etheridge, 1881 fide Gilliland, 1993), Slovakia (Kozur et al., 1976) China (Ding, 1985; Zhang, 1983; 1985; 1993), and the Cantabrian Mountains (NW Spain; herein).

?Eocaudina subhexagona Gutschick, Canis \& Brill, 1967 (Fig. 5b)

*1967 Eocaudina subhexagona n. sp.; Gutschick et al., p. 1469 , pl. 186, figs 16-21, pl. 187, fig. 18. 1968b Eocaudina subhexagona, Gutschick et al.; Mostler, p. 12, pl. 2, fig. 4.

1973 Eocaudina subhexagona Gutschick et al.; Matyla et al., p. 141-142, pl. 1, fig. 22, 24-29, pl. 2, fig. 4 [cum syn.].

1976 Eocaudina subhexagona Gutschick et al.; Kozur et al., p. 12 .

1977 Eocaudina subhexagona Gutschick et al.; Wernlund, p. 55-56, pl. 2, figs 8-10.

?1980 Eocaudina subhexagona Gutschick et al.; Ebner \& Fenninger, p. 6-7, pl. IV, fig. 3.

1985 Eocaudina subhexagona Gutschick et al.; Ding, p. 342 , pl. 3, fig. 3 .

2001 Eocaudina? subhexagona Gutschick et al.; Boczarowski, p. 145, text-fig. 66C-F.

2013 818. subhexagona Gutschick et al., 1967; Eocaudina; Reich, p. 49.

?pars2015 Eocaudina subhexagona, Gutschick et al.; Nouredini et al., p. 166, pl. 1, figs 1-9.

Material. 41 fragments, all from sample M13. 3 catalogued specimens (GIK 1413-24, GIK 1413-30, GIK 1416-4).

Description. Slightly arched sieve plate; fragile skeletal lattice and well-developed hexagonal, relatively small pores; no thickened margin; always only fragmentary preserved.

Remarks. Our form is close to Eocaudina subhexagona Gutschick et al., 1967 although originally described as stronger curved, up to hemispherical, and with in part larger pores. The attribution to Eocaudina and thus to the holothurians is doubtful because similar ossicles were reported from further echinoderm classes (see Boczarowski, 2001).

Distribution. Devonian of Poland (Matyja et al., 1973; Boczarowski, 2001) and Bulgaria (Ebner \& Fenninger, 1980), Mississippian of the United States (Gutschick et al., 1967) and the Cantabrian Mountains (NW Spain; herein).

\section{Eocaudina? sp.}

(Fig. 5c)

Material. 1 specimen, sample M13 (GIK 1413-21).

Description. Triangular, slightly concavo-convex sieve structure with typical Eocaudina disposition of subhexagonal to hexagonal pores. Two sides are marginal thickened; the third one is irregular (fractured ?). 


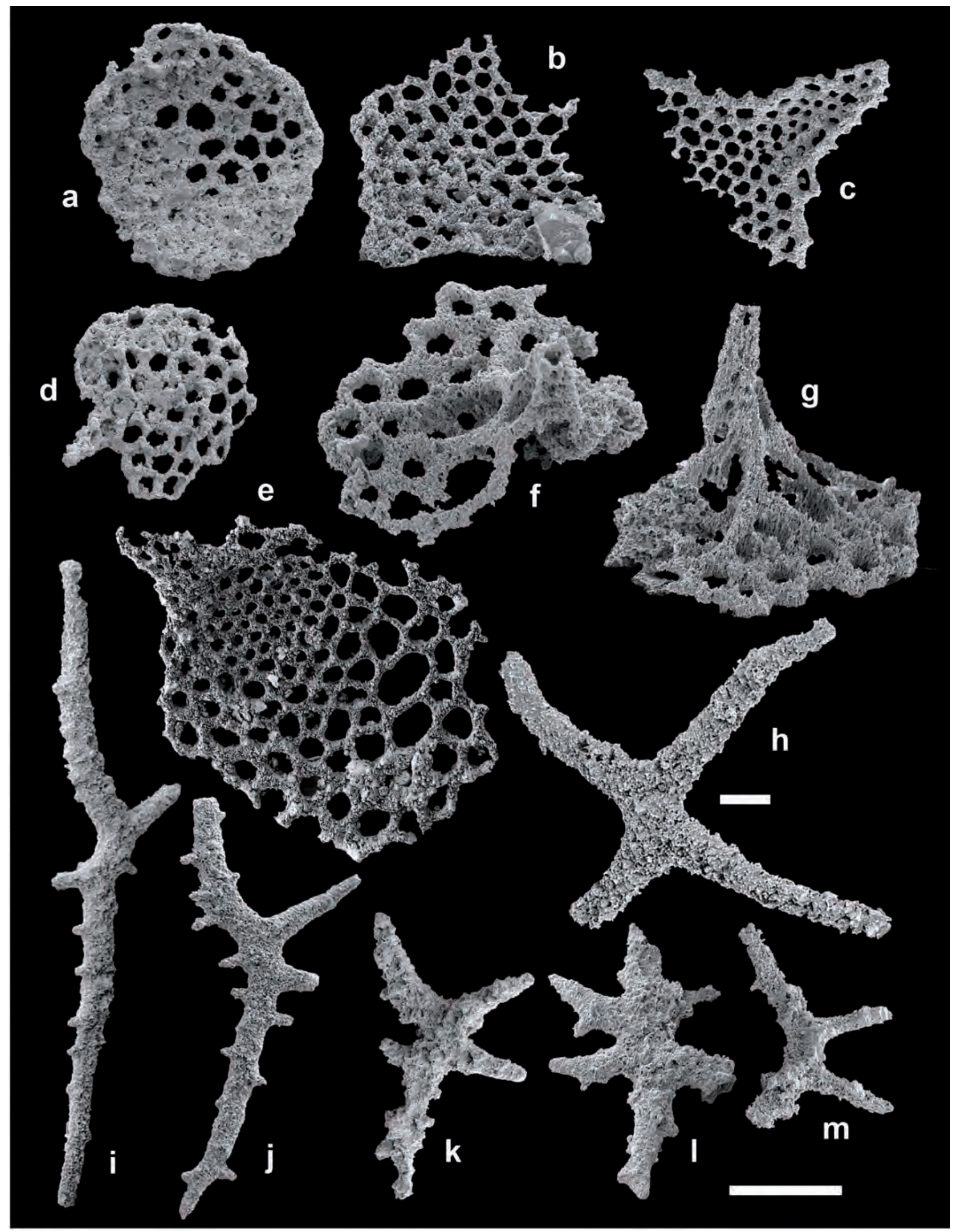


Remarks. Somewhat similar is an indeterminate echinoderm remain, questionable attributed to holothurians by Kozur \& Mostler (1989; pl. 2, fig. 2) from the Permian of Sicily.

Distribution. Carboniferous (Serpukhovian) of the Cantabrian Mountains (NW Spain, herein).

Genus Spicatocaudina Kozur \& Mostler, 1989

Type species Eocaudina spicata (Gutschick, 1959) emend. Frizzell \& Exline, 1966

Remarks. Kozur \& Mostler (1989) grouped late Palaeozoic Eocaudina morphotypes with a marginal or submarginal spine-like shaft to the new genus Spicatocaudina Kozur \& Mostler, 1989 of unknown taxonomic affinity. The distinctive morphology justifies separation of an own genus. However, herein we follow earlier authors who attributed the taxon to the holothurians.

Spicatocaudina spicata (Gutschick, 1959)

(Fig. 5d)

*1959 Thuroholia spicatus sp. nov.; Gutschick, p. 132, pl. 25, figs 3, 4, 7-9.

1966 Eocaudina spicata (Gutschick); Frizzell \& Exline, p. U659.

1967 Eocaudina spicata (Gutschick); Gutschick et al., p. 1468-1469, pl. 186, figs 35-37, pl. 187, figs 21, 25.

2012 Eocaudina spicata (Gutschick); Gao et al., p. 184 , pl. 3, fig. 4.

2013 789. spicatus Gutschick, 1959; Thuroholia; Reich, p. 48.

Material. 15 fragments, all from sample M13. 4 catalogued specimens (GIK 1413-29, GIK 1415o-1415q).

Description. Slightly concave-convex forms with subcircular to elliptical outline; pores polygonal-hexagonal, but poorly formed oval to irregular; lattices relatively thin; scalloped rim; marginally one distinct spine-like process which projects outwards at a small angle with the plane of the plate.
Remarks. S. spicata has a great morphological variability. Neither the curvature of the plate, the length of the spine nor the form of the pores is strictly defined. Significant is the existence of the spine-like process.

Distribution. S. spicata is known from the Mississippian of the U.S. Midwest (Gutschick, 1959; Gutschick et al., 1967), the Serpukhovian of the Cantabrian Mountains/ NW Spain (herein), and the Pennsylvanian of the Shanxi Province, northern China (Gao et al., 2012).

Spicatocaudina cf. spicata

(Fig. 5e)

Material. 1 specimen, sample M13 (GIK 1415-32).

Description. Only very slightly arched, elongated sieve plate with nearly 100 subcircular pores; distinct marginal spine-like pointed process, projected outwards at a small angle and also perforated. Delimited area beside the spine with equal sized small pores surrounded by larger ones; at the opposite side the eocaudina disposition is partly disrupted by fused pores forming large oval ones. Lattices relatively thin. Outer margin partly irregular due to incomplete pores.

Remarks. The marginal process of this ossicle and that of Spicatocaudina spicata are quite similar. Otherwise, the irregular sized pores differ from S. spicata. Apart from the process, the delimited area of small pores surrounded by larger ones resembles Thuroholia cribriformis Gutschick, 1954. Zhang (1983) reported a similar form with one pointed process from the Mississippian of Hunan/China as Paracucumarites sp. attributed to the Holothuroidea.

Distribution. Mississippian (Serpukhovian) of the Cantabrian Mountains (NW Spain, herein).

Parafamily Priscopedatidae Frizzell \& Exline, 1956 emend. Gilliland, 1992

Priscopedatidae gen. et sp. indet. (Figs $5 \mathrm{f}-\mathrm{g}$ )

Material. 1 specimen, sample M13 (GIK 1413-23).

Figure 5. Eocaudinid sieve plates, table plate and rods. All from sample M13, except specimen h, which is from sample RF2. a) Eocaudina mccormacki Frizzell \& Exline, 1956 (GIK1413-26). b) ?Eocaudina subhexagona (GIK1413-24). c) Eocaudina? sp. (GIK1413-21). d) Spicatocaudina spicata (Gutschick, 1959) (GIK1413-29). e) Spicatocaudina cf. spicata (GIK141532). f-g) Priscopedatid table plate, seen from oblique above (f) and laterally (g) (GIK1413-23). h-m) Holothuroid rods. (h) Tetravirga sp. (GIK1412-RF2-5). (i-m) Inc. sed. (?"Palelpidia/Praeeuphronites-Group") (GIK1415-R1 to R4, 1413$\mathrm{K} 1)$. Scale bars $=0.1 \mathrm{~mm}$. 
Description. Table plate with a basal Eocaudina-like close-packed subcircular sieve plate and a prominent (eccentrically?) stirrup with height nearly the same than width of the basal plate. Several in part intertwined trabeculae at the base of the stirrup rise up and fuse to form an acute regular four-pillared hollow structure. Transversal branches between the pillars are recognizable.

Remarks. Gilliland (1992, 1993) emended the Priscopedatidae to include spired plates, as there are morphological intergradations from table plates. In fact, interwined lattices at the base of the stirrup in our specimen are a feature of spired plates. The unique Palaeozoic priscopedatid table plates we found in literature were described by Mostler \& Rahimi-Yazd (1976) from the late Permian of northern Iran: Priscopedatus quinquespinosus and Priscopedatus sp., the latter not included in the genus by Gilliland (1993) due to insufficient description and fragmentary preservation. The morphologically strongly differing Spanish form belongs to a new paragenus, but the material is not sufficient to erect a formal taxon.

Distribution. Mississippian (Serpukhovian) of the Cantabrian Mountains (NW Spain; herein).

Order ELASIPODIDA Théel, 1882

Parafamily Stichopitidae Frizzell \& Exline, 1956 [pars]

"Palelpidia/Praeeuphronides group" sensu Gilliland, 1993

Genus Tetravirga Frizzell \& Exline, 1956

Type species Tetravirga imperforata Frizzell \& Exline, 1956

Remarks. Gilliland (1993) discussed the taxonomically enigmatic "Palelpidia/Praeeuphronides group" including as oldest genus Tetravirga from the Upper Mississippian. Already Mostler (1968b) suggested that Praeeuphronides Mostler, 1968a, Multivirga Mostler, 1968b, and Tetravirga belong to one holothurian species. However, the large morphological ranges might be due to convergences within a polyphyletic group. Therefore, further taxonomic treatment needs thorough study of additional material.

\section{Tetravirga sp.}

(Fig. 5h)

Material. 1 specimen, sample RF2 (GIK1412-RF2-5).

Description. Flat, regular cross-shaped, moderately preserved ossicle. One shorter arm probably only fragmentary preserved. The centre of the cross has an only hardly recognizable circular impression.
Remarks. Our specimen is identical to Tetravirga fordalensis [sic!] of Etheridge (1881) fide Gilliland (1993; pl. 11, figs 5-6) with better recognizable circular impression at the centre. However, both differ from the correctly spelled T. fordelensis Frizzell \& Exline, 1956, which has a rosette-like central portion with four perforations and a spinose, often not preserved spire rising from the centre. $T$. etheridgei Frizzell \& Exline, 1956 also has a central portion pierced by four perforations and could be synonymous to $T$. fordelensis (Gilliland, 1993). Also T. sinensis (Zhang, 1986a; Wernlund, 1996) has four central perforations, but differs by its extended central junction. T. imperforata Frizzell \& Exline, 1956 has a distinct short, smooth conoidal central spine. Also Tetravirga. n. sp. reported by Mostler \& RahimiYazd (1976) has a central spine, in addition to much more enlarged arm ends. T. perforata Mostler, $1968 \mathrm{~b}$ and T. curta Frizzell \& Exline, 1956 are clearly different because of their much shorter arms. Arms of tetraradiate morphotypes of Praeeuphronites do not radiate from a central cross, but pairwise from the ends of a short central rod.

Our specimen as well as the T. fordalensis [sic!] of Gilliland (1993) might belong to a new spineless species. They also might represent $T$. imperforata without the preserved central spine, showing only a basal circular impression. In fact, Wernlund (1996) described $T$. imperforata from the Pennsylvanian of Texas with and without central spine or apophysis. Very similar is also the apparently spineless Tetravirga sp. A of Zhang (1986a) from the Mississippian of China.

Distribution. Spineless Tetravirga sp. is reported from the latest Viséan of Scotland (Etheridge, 1881 sensu Gilliland, 1993), the Serpukhovian of the Cantabrian Mountains (NW Spain, herein), and tentatively from the Mississippian of China.

Indeterminate rod-like elements. (Figs $5 \mathrm{i}-\mathrm{m}$ )

Material. 6 specimens, sample M13 (GIK 1413-K1, GIK 1415-R1 to R4, GIK 1414-M4-1).

Description. Solid, very slightly undulating, up to $0.6 \mathrm{~mm}$ long main bar with small notches $(0.01 \mathrm{~mm})$. In the central part of the main bar one pair or two opposite pairs of longer arms (up to $0.1 \mathrm{~mm}$ ) which diverge at characteristic acute angle of about $40^{\circ}-50^{\circ}$. All bars remain in one plane.

Remarks. Rod-like elements occur in several echinoderm groups and beyond, e.g. in sponges. Concerning holothurians, some similarity exists with elements of the Elasipodida. Thus, the superficial similarity with Tetravirga sp. (Fig. 5h) has to be noted. Siliceous (hexactinellid) sponge spicules occur in our samples, but the assignment 
of the calcareous elements remains obscure. In general, sponge macrofossils are not known from the Genicera Fm. (see e.g. García-Bellido, 2002; García-Bellido \& Rigby, 2004), therefore we tend to attribute the rods to the echinoderms, and among them, following Weber (pers. comm. 2018), to the holothurians. Be that as it may, the rods are figured as a distinctive, easily recognizable faunistic element. They could represent different ontogenetic stages; larger specimens might result from extensive allometric growth of the main bar.

Distribution. Carboniferous of the Rhenish Mountains/ Germany (Weber, pers. comm. 2018) and Cantabrian Mountains (NW Spain/herein).

(without rank) APODIDA Brandt, 1835 (sensu Östergren, 1907)

Parafamily Palaeochiridotidae Frizzell \& Exline, 1966 emend. Gutschick et al., 1967 [pars]

Genus Langepis Kozur \& Mostler, 2008

Type species Rota campbelli Gutschick, 1959

Remarks. Kozur \& Mostler (2008) introduced the monotypic genus Langepis for wheel-shaped ossicles with 4-10 short spokes, a single central perforation and a smooth rim without additional peripheral rings of pores, establishing "Rota campbelli" Gutschick, 1959 as the type species. They restricted the likewise monotypic genus Rota to wheel-shaped ossicles with two, rarely three peripheral rings of pores with Rota martini Langenheim \& Epis, 1957 remaining as type species. Initially, Gutschick et al. (1967) proposed both species to be synonymous, an issue also mentioned but not further discussed by Gilliland (1993).

Langepis campbelli (Gutschick, 1959)

(Figs 6a-c)

pars 1957 Rota martini n. sp.; Langenheim \& Epis, p. 170, pl. 1, figs 17-18, 20, 23, 25 [only].

*1959 Rota campbelli, n. sp.; Gutschick, p. 135-136, pl. 26, figs 1-21, 26, 27, 32-35, text-fig. 4.

1967 Rota campbelli Gutschick; Gutschick et al., p. 1474, pl. 187, figs $1-6,23$, pl. 188, figs $1-2,8-9,14$ $15,21-23,28-31,36,40-43$, text-fig. $4(1,5,15,21-$ $22,27-28,33,36)$.

1984 Rota campbelli Gutschick; Sandberg \& Gutschick, pl. 8 , fig. G.

2013 121. campbelli Gutschick, 1959; Rota; Reich, p. 34.
Material. 3 specimens, sample M13 (GIK 1415-5, GIK 1415-7, GIK 1412-M13-3).

Description. Wheel-shaped ossicles with 6-8 spokes separated by subtriangular to suboval spoke interspaces with radial orientated long axis; spokes slightly arched towards the dorsal side and tapering towards the undulated to polygonal outer line; smooth rim. Concavo-convex relatively small central area with a perforation in the middle (in Fig. 6b diagenetically obscured); diameter 190-250 $\mu \mathrm{m}$.

Remarks. The finding of wheel-shaped ossicles within ophiocistioids by Haude \& Langenstrassen (1976a) led to confusion concerning their taxonomic assignment. One essential differing feature is a tripartite central structure at the ventral side of the ophiocistioid wheels. Boczarowski (1997) revised and reassigned several taxa, supposing inter alia that the specimen figured by Sandberg \& Gutschick (1984) as Rota campbelli might belong to the ophiocistioid Protocaudina Croneis in Croneis \& Mccormack, 1932. However, several authors like Reich \& Mostler (2002), Reich (2010a, 2012), and Nouredini et al. (2015) continued to assign wheel-shaped ossicles with a tripartite or tetrapartite central ventral structure like Protocaudina and Microantyx to the holothurians. Reich (2012) stressed the fact that similar post-Triassic wheel-shaped ossicles, not considered by Boczarowski (1997), are unequivocal holothurians, as ophiocistoids became extinct during the Triassic (Reich et al., 2018).

Distribution. Lower Mississippian of Arizona, Indiana, Missouri and Montana (USA). Apart from our Serpukhovian findings in the Cantabrian Mountains (Spain), also Kozur and Mostler (2008) mentioned Mississippian occurrences in Europe, but without further details. Reich (pers. comm. 2018) mentioned an unpublished occurrence from the Viséan of the Rügen Island (Baltic Sea, core Dranske 1/68).

Genus Rotoides Gutschick et al., 1967

Type species Rotoides tretomesota Gutschick et al., 1967

Remarks. According to Gutschick et al. (1967) the genus Rotoides is similar to the genus Langepis, but the first has more spokes ( 8 to 12) and a larger central area without any perforation or central dome. The smooth rim and the lack of an accentuated dorsal central dome differentiate Rotoides from Carboniferous Theeliidae Frizzell \& Exline, 1956. 


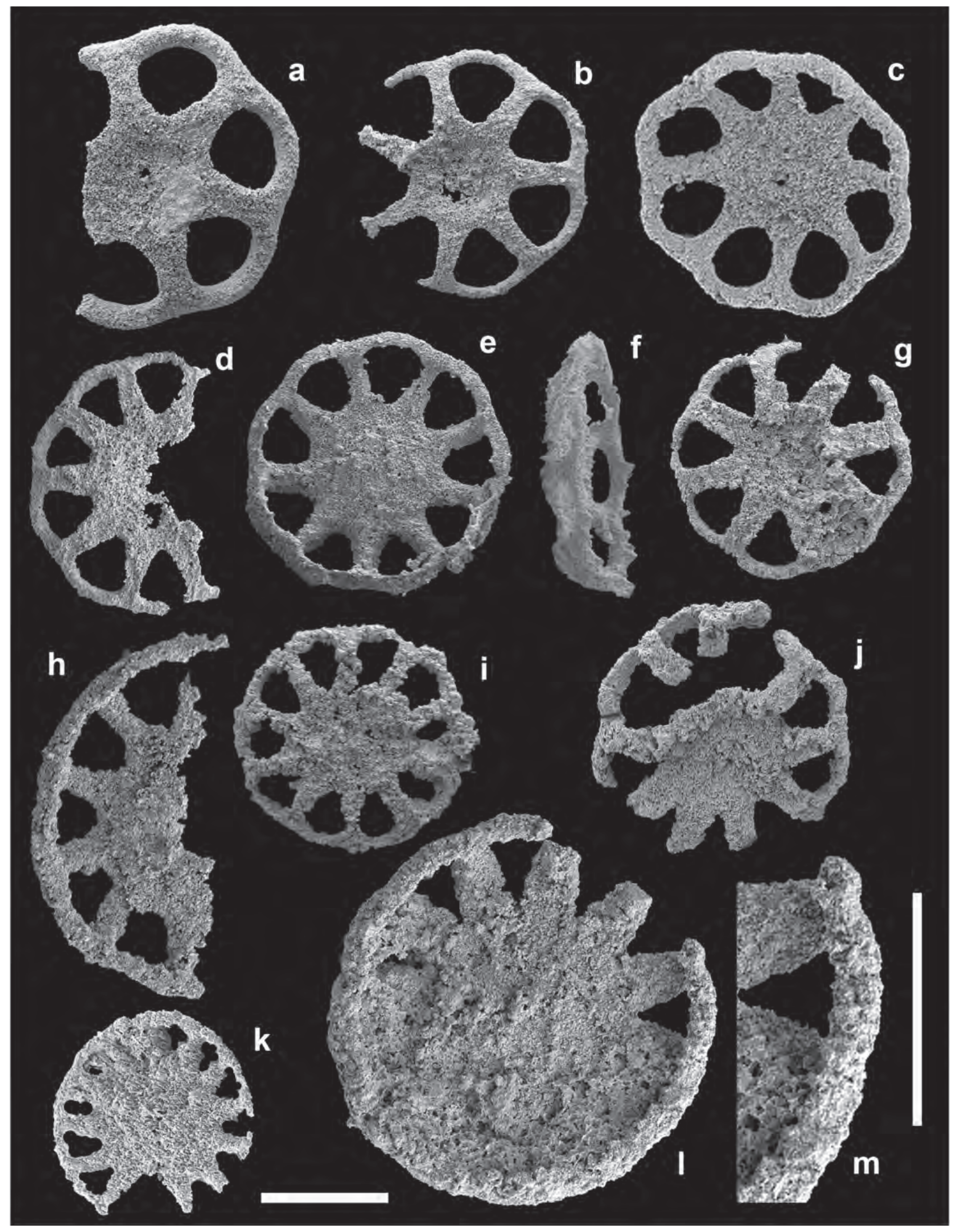


Rotoides sp.

(Figs $6 \mathrm{~d}-\mathrm{j}$ )

Material. 7 specimens. 1 of sample M4 (GIK 1414M4-R1), 1 of sample M9 (GIK 1414-M9-R1) and 5 of sample M13 (GIK 1415-6, GIK 1413-4, GIK 1413-5, GIK 1413-6, GIK 1413-7).

Description. Circular, mostly slight undulated ossicles; 8-12 spokes, slightly arched and getting thinner towards the rim; spoke interspaces triangular to subtriangular; smooth rim bent in different rates inward towards the dorsal side. Central area nearly half the diameter of the ossicle, slightly domed towards the dorsal side and without any perforation or ornamentation, neither on the ventral side, nor on the dorsal side. Diameters from 180-280 $\mu \mathrm{m}$, in average $200 \mu \mathrm{m}$.

Remarks. Very similar is Rotoides imperforata Gutschick et al., 1967. Our specimens differ by a smaller central area and bigger spoke interspaces. Concerning Rotoides imperforata, Kozur (1984a) postulated that the species cannot be distinguished from Theelia Schlumberger, 1890 and called a single Moscovian specimen from the Bükk Mountains/Hungary Theelia imperforata (Gutschick et al., 1967), not followed by Reich (2013). Remarkable is the great similitude between our forms and wheelshaped ossicles of the ophiocistioid Rotasaccus dentifer Haude \& Langenstrassen, 1976a, only discernible by the characteristic central tripartite ornamentation on the ventral side of the latter (see Haude \& Langenstrassen, 1976a). Rotoides sp. also resembles Microantyx morphotypes, but in this case a tetrapartite central structure on the ventral side of the latter is the differing feature (e.g. Boczarowski, 1997; Bohatý \& Herbig, 2010; Nouredini et al., 2015).

Distribution. Mississippian of the USA (Indiana, Missouri, Montana), Serpukhovian of Spain (Cantabrian Mountains, herein).

Paleochiridotidae gen. et sp. indet.

(Figs $6 \mathrm{k}-\mathrm{m}$ )
Material. 2 specimens, sample M13 (GIK 1412-M13-8, GIK 1415-4).

Description. Flat, circular ossicles with respectively 12 and 14 short and thick spokes separated by triangular interspaces; turned-up rim with regular continuous fine denticulation (Fig. 6m); large central area, more than half the diameter of the ossicle. Considerable size range: $160-310 \mu \mathrm{m}$.

Remarks. We did not find similar wheel-shaped ossicles in literature and kept the sparse material in open nomenclature. General characters, especially the fine regular and continuous denticulation of the rim, resembles modern wheel-shaped ossicles of the Apodida (compare e.g. Gilliland, 1993; Smirnov, 1998).

Distribution. Serpukhovian of the Cantabrian Mountains (Spain, herein).

Class OPHIOCISTIOIDEA Sollas, 1899

Order unnamed

Family Linguaserridae Reich \& Haude, 2004

Genus Linguaserra Langer, 1991 emend. Reich, 2007

Type species Linguaserra ligula Langer, 1991

Remarks. Linguaserra was earlier placed in the Rotasaccidae Haude \& Langenstrassen, 1976a, but separated by Reich \& Haude (2004) in an own family, which is interpreted to be a conservative stem-line of the ophiocistioids, reaching from the early Silurian to the Upper Triassic (Reich \& Haude, 2004; Reich, 2010a; Reich et al., 2018). The supposed second genus of the family, Rogeriserra (in Reich \& Smith, 2009), remained a nomen nudum, and was excluded from Linguaserridae by Reich (2007). Its exact systematic position is unknown, but is supposed intermediate between ophiuroids and ophiocistioids (Reich \& Smith, 2009).

Figure 6. Apodid wheel-shaped ossicles. a-c) Langepis campbelli (Gutschick, 1959). Sample M13. (a) Specimen with 6 spokes, ventral view (GIK1415-5). (b) Specimen with 7 spokes, ventral view (GIK1415-7). (c) Specimen with 8 spokes, dorsal view (GIK1412-M13-3). d-j) Rotoides sp. (d) Fractured specimen with originally 10 spokes, ventral view (GIK1415-6). Sample M13. (e-f) Specimen with 9 spokes, dorsal view (e), lateral view (f) (GIK1413-4). Sample M13. (g) Specimen with 8 spokes, ventral view (GIK1413-5). Sample M13. (h) Fractured specimen with originally up to 12 spokes, dorsal view (GIK1414-M9-R1). Sample M9. (i) Specimen with 10 spokes, ventral view (GIK1414-M4-R1). Sample M4. (j) Specimen with 9 spokes, ventral view (GIK1413-6). Sample M13. k-m) Paleochiridotidae gen. et sp. indet. Dorsal views. Sample M13. (k) Specimen with 14 spokes (GIK1412-M13-8). (I) Specimen with 12 spokes, majority of spoke interspaces obscured by infilling (GIK1415-4). (m) Amplified (x2) detail of specimen 61 with hardly recognizable but definitely uniformly very fine denticulated rim. Scale bars $=0.1 \mathrm{~mm}$. 


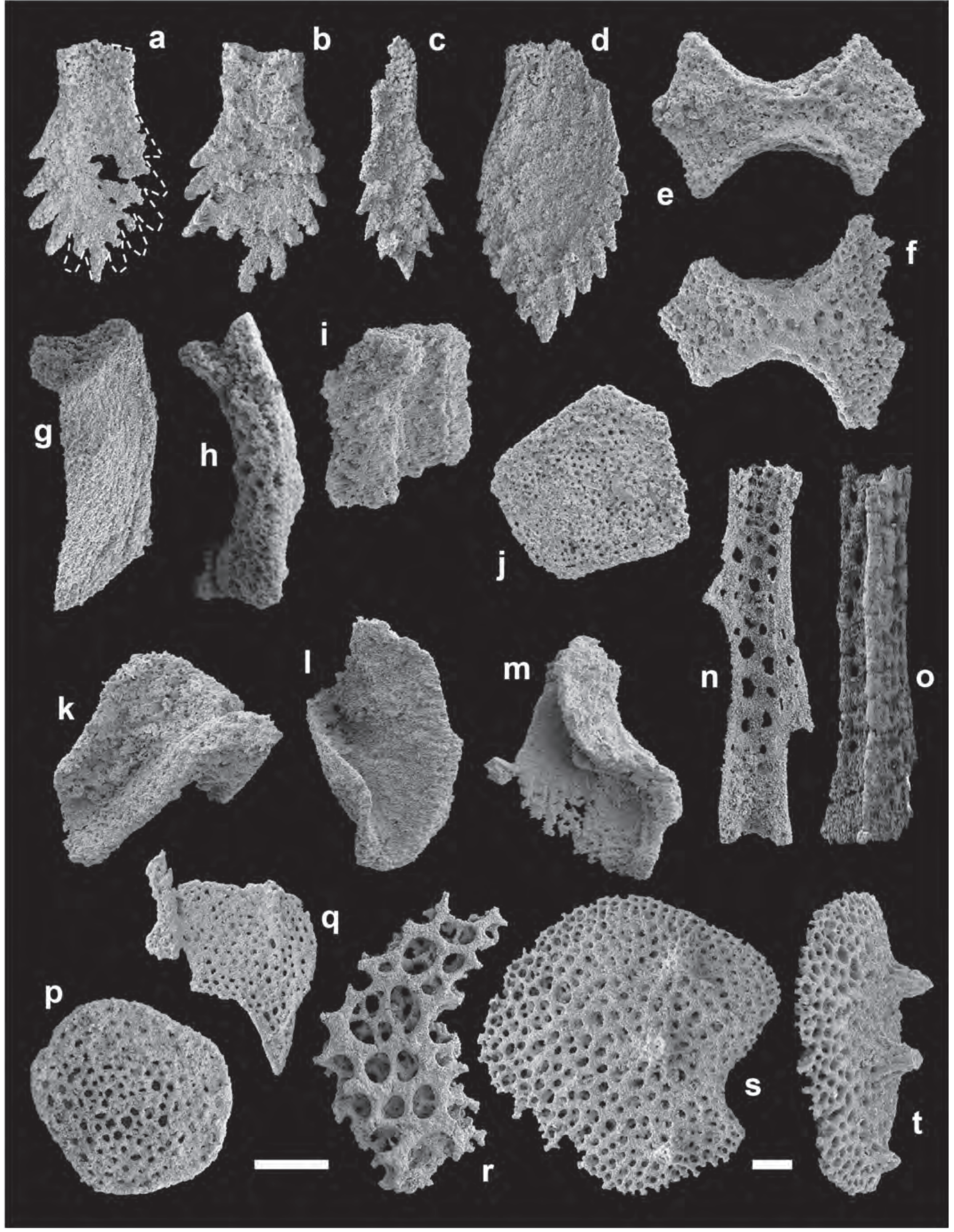




\section{Linguaserra heidii $\mathrm{n}$. sp.}

(Figs $7 \mathrm{a}-\mathrm{b}$ )

1997 Linguaserra sp.; Weber, p. 489, pl. 1, fig. 1.

2004 sp. sensu Weber (1997), Linguaserra; Reich \& Haude, p. 494.

2014 Linguaserra. sp. sensu Weber (1997); Reich \& Kutscher, fig. 2(3).

2018 Linguaserra. sp. sensu Weber (1997); Reich et al., p. 5, fig. 5(3).

Derivatio nominis. In honour of Hans Martin Weber (Bergisch-Gladbach), nicknamed Heidi, who described the species first in open nomenclature.

Holotype. The specimen GIK 1415-3 from sample M13 (Fig. 7a).

Paratype. The specimen GIK 1413-1 from sample M13 (Fig. 7b).

Additional material. Not available.

Type locality, type horizon and age. Millaró de la Tercia (Cantabrian Mountains, NW Spain); uppermost bed of the Millaró Beds (upper Serpukhovian).

Diagnosis. Small, slightly concavo-convex, bilateral symmetric goniodont with a central main tooth and five divergent discrete lateral teeth on each flank; shape of the serrate axial part oval; abaxial part shorter and narrower than the teeth-bearing axial part; abaxially fine-pored.

Description. Slightly arched, slender lance-shaped goniodont; acute central main tooth of similar size than the five acute divergent lateral teeth on each flank, only the most distal ones slightly smaller; all teeth relatively long, well developed, discrete and laterally not fused. Due to the divergence of the lateral teeth, the shape of the serrate part is rather oval. The abaxial part is narrower than the teeth-bearing part and covered with fine pores as described by Haude \& Reich (2004) for the Linguaserridae. Adoral (inner) surface of the goniodont slightly concave. For measurements see Table 2 .

Remarks. The genus Linguaserra includes five known species. These are L. franzenae Reich \& Kutscher, 2014 from the Llandovery (early Silurian) of Gotland (Sweden), L. ligula Langer, 1991 from the Eifelian to Givetian (Middle Devonian) of the Rhenish Mountains (Germany), L. spandeli Reich, 2007 from the Zechstein (uppermost Permian) of Thuringia (Germany), L. triassica Reich in Reich et al., 2018 from the Upper Triassic of the Dolomites (N Italy) and the new species L. heidii $\mathrm{n}$. sp., which hitherto was known from the uppermost Tournaisian (Mississippian) of the Rhenish Mountains (Richrath Mb. of Heiligenhaus Fm., see latest biostratigraphic and sequence stratigraphic data in Bábek et al., 2010 and Herbig, 2016). Linguaserra heidii $\mathrm{n}$. sp. is the smallest and most slender lanceolate species with an expressed pinched abaxial part (Table 2). L. franzenae is tongue-shaped, L. ligula acute pole-shaped, and $L$. spandeli is similar in outline to $L$. heidii $\mathrm{n}$. sp., but wider and more compact. In outline, $L$. triassica is related to $L$. spandeli, but distinct from all other species by its ridged lateral denticles. Compared to all other species, the long teeth of L. heidii $\mathrm{n}$. sp. are exceptionally discrete.

Distribution. Uppermost Tournaisian of the Rhenish Mountains (Germany) and Serpukhovian of the Cantabrian Mountains (NW Spain).

\section{Linguaserra $\mathrm{cf}$. heidii}

(Fig. 7c)

Material. 1 specimen, sample M13 (GIK 1415-2).

Description. Small, extremely slender, nearly flat, symmetrical goniodont; acute central main tooth, four acute divergent and discrete lateral teeth on each flank (partly broken) nearly as big as the main tooth; long and slender, pinched abaxial part, fine-pored. For measurements see Table 2 .

Figure 7. Ophiocistioids and indeterminate echinoderm ossicles. Sample M13. a-b) Linguaserra heidii n. sp., aboral views. (a) Holotype (GIK1415-3), (b) paratype (GIK1413-1). c) Linguaserra cf. heidii (GIK1415-2), aboral view. d) Linguaserra $\mathrm{n}$. sp. (GIK1415-1), aboral view. e-f) Ossicle type A. Ophiocistioid perradialia? (GIK1413-01, 1415-02). g-i) Ossicle type B. Affinity unknown. (g) Oblique view of smooth surface (GIK1415-14). (h) Lateral view (GIK1415-15). (i) Oblique view of opposite side with central furrow and parallel running ridge ending in a crest, fractured; lower half is not preserved (GIK1415-13). j) Ossicle type C. Plate of a crinoid calyx? (GIK1413-08). k-m) Ossicle type D. Ophiuroid lateral arm plates? (k) GIK1413-05. (l) GIK1415-12. (m) GIK1415-16. n-o) Ossicle type E. Holothurian anal teeth? (n) with spiny processes, inner (?) view (GIK1413-12), (o) without processes, lateral view (GIK1413-13). p-q) Ossicle type F. ?Eocaudina irregularis (p) Circular outlined (GIK1413-25). (q) Biconcave-convex outlined (GIK1413-28). r-t) Ossicle type G. ?Mortensenites teat. (r) Fragment? (GIK1413-27). (s-t) GIK1413-20. (s) Outer (?) surface. (t) Lateral view. Scale bars $=0.1 \mathrm{~mm}$. 
Table 2 Measurements of discussed Linguaserra species using parameters defined by Haude \& Langenstrassen (1976b) and Reich et al. (2018). $\mathbf{Z}^{\prime}$ : maximum length. $\mathbf{z}^{\prime}$ : length of the serrate axial part. B: maximum width. R: width axial part/width abaxial part ratio; $>1$ means that the abaxial part is pinched (lance-shaped), $<1$ the opposite (tongue-shaped). $\mathbf{n}$ : number of denticles per flank. F: length of serrate flank (without main denticle). DI: denticle index for small goniodonts (number of denticles at flank per $0.1 \mathrm{~mm}$ ). *Own meassurements of specimens figured without corresponding values. In brackets values of Reich (2018).

\begin{tabular}{|c|c|c|c|c|c|c|c|c|}
\hline species or specimen & $Z^{\prime}(\mu \mathrm{m})$ & $\mathrm{z}^{\prime}(\mu \mathrm{m})$ & $\mathrm{B}(\mu \mathrm{m})$ & $\mathrm{R}$ & $\mathrm{Z}^{\prime} / \mathrm{B}$ & $\mathrm{n}$ & $\mathrm{F}(\mu \mathrm{m})$ & DI \\
\hline $\begin{array}{l}\text { Linguaserra heidii } \mathrm{n} . \mathrm{sp} . \\
\text { (holotype, herein) }\end{array}$ & 333 & 180 & 186 & $>1$ & 1.79 & 5 & 162 & 3.1 \\
\hline $\begin{array}{l}\text { Linguaserra sp. } \\
\text { sensu Weber, } 1997\end{array}$ & $246^{*}$ & $100 *$ & $126^{*}$ & $>1$ & $(1.95)$ & $5-6$ & $113^{*}$ & $(5.1)$ \\
\hline $\begin{array}{l}\text { L. cf. heidii } \\
\text { (herein) }\end{array}$ & 340 & 150 & 120 & $>1$ & 1.8 & 4 & 113 & 3.5 \\
\hline $\begin{array}{l}\text { L. spandeli } \\
\text { Reich, } 2007 \\
\text { (holotype) }\end{array}$ & $316^{*}$ & $157^{*}$ & $184^{*}$ & $>1$ & $(2.4)$ & $6-7$ & $152^{*}$ & $(4.1)$ \\
\hline $\begin{array}{l}\text { L. ligula } \\
\text { Langer, } 1991 \\
\text { (holotype) }\end{array}$ & $670^{*}$ & $380^{*}$ & $340^{*}$ & $<1$ & $(1.95)$ & $9-10^{*}$ & $360^{*}$ & $(2.8)$ \\
\hline $\begin{array}{l}\text { L. franzenae } \\
\text { Reich \& Kutscher, } 2014 \\
\text { (holotype) }\end{array}$ & 823 & $485^{*}$ & 486 & $<1$ & 1.69 & $7-8$ & 523 & $(1.6)$ \\
\hline $\begin{array}{l}\text { L. triassica } \\
\text { Reich, } 2018 \\
\text { (holotype) }\end{array}$ & 484 & 230 & 284 & $>1$ & 1.7 & 11 & 253 & 4.4 \\
\hline $\begin{array}{l}\text { Linguaserra n. sp. } \\
\text { (herein) }\end{array}$ & 420 & 210 & 210 & $>1$ & 2 & 6 & 180 & 3.3 \\
\hline
\end{tabular}

Remarks. The specimen strongly resembles $L$. heidii n. sp., but is still more slender and has only four discrete teeth on each flank.

Distribution. Only known from the Upper Mississippian (Serpukhovian) of the Cantabrian Mountains, NW Spain.

\section{Linguaserra $\mathrm{n} . \mathrm{sp}$.}

(Fig. 7d)

Material. 1 specimen, sample M13 (GIK 1415-1).

Description. Lance-shaped nearly symmetrical, only very slightly arched goniodont. Acute long central tooth, about double size than the lateral teeth; six lateral teeth on each side, fused at their bases, width and length approximately equal, all running subparallel to the median axis, resulting in a regular triangular-shaped outline of the serrate part of the goniodont. Abaxial and axial part of nearly equal length; width of abaxial part tapering slightly towards the fine-pored distal end. Negative impression of the subsequent goniodont of the teeth battery recognizable: the distance between the tips of the main denticles of two consecutive goniodonts (Haude \& Langenstrassen, 1976b) is $0.1 \mathrm{~mm}$. For further measurements see Table 2 .

Remarks. Linguaserra n. sp. is clearly separated from the slender $L$. heidii $\mathrm{n}$. sp. It is the second species of the rare genus recognized in the Carboniferous. As only a single specimen is available we keep it in open nomenclature. Using the published plot of Reich et al. (2018) of denticle index (DI) versus total length/maximum width (Z'/B), Linguaserra n. sp. (Z'/B $=2.0$, DI $=$ 3.3) would plot just between L. ligula and L. spandeli. However, considering the typical lance-shaped outline of late Palaeozoic Linguaserridae (Reich \& Kutscher, 2014), Linguaserra $\mathrm{n}$. sp. is closer to L. spandeli.

Distribution. Upper Mississippian (Serpukhovian) of the Cantabrian Mountains (NW Spain, herein).

Indeterminate echinoderm ossicles

(Figs 7e-t) 
Ossicle type A. (Figs 7e-f) Elongate planar ossicle, symmetrical along long axis and short axis as well, strongly biconcave along long axis and with bluntly acute tips with slightly concave margins. Raised rims along the indentations on the longitudinal sides only on supposed external face of the ossicle (Fig. 7e), but missing on the supposed internal face (Fig. 7f). Such indentations with a slightly raised border are characteristic for podial pores, i.e. the passage for tube feet between ambulacralia. On the one hand, they remind flooring plates of some edrioasteroids (Zamora, pers. comm. 2019). On the other hand, the similitude with perradialia of ophiocistoids is tempting. According to Ubaghs (1966) their perradialia are typically cross-shaped and tetraconcave. The shape is independent from integration as plates in a hard corona in phylogenetic old groups or as isolated ossicles in younger groups from the Middle Devonian onwards (see reconstruction of the Middle Devonian (Givetian) Rotasaccus dentifer in Haude \& Langenstrassen, 1976a). However, Reich \& Mostler (2002) noted that from the Carboniferous and Permian from ophiocistioids hitherto only isolated goniodonts are known.

Ossicle type B. (Figs 7g-i) The slightly concavoconvex ossicles have a convex outer surface with a very dense stereom (Fig. 7g), and a concave inner surface with a coarse-meshed labyrinthic stereom (Figs $7 \mathrm{~h}-\mathrm{i}$ ). A ridge and an adjacent furrow run along the inner surface (Fig. 7i). The ridge ends on both extremes in a crest, being one more accentuated. This quite frequent ossicle in the residues of sample M13 remains of unknown affinity.

Ossicle type C. (Figs 7j) Pentagonal flat plate resembling a calyx plate of a crinoid, but also echinoids and edrioasteroids have similar plates.

Ossicle type D. (Figs 7k-m) Different views of a curved to corrugated ossicle resembling lateral arm plates of ophiuriods, which might wrap the vertebrae.

Ossicle type E. (Figs 7n-0) Elongate, half-tube shaped ossicles seen from its inner side (Fig. 7n) and laterally (Fig. 7o) with numerous pores; without or with small spiny process projected asymmetrical on each side. Somewhat similar structures were reported by Boczarowski (2001) from the Devonian of Poland and interpreted as anal teeth of holothurians, concretely of Dendrochirotida, even though the spiny processes of his elements are mostly arranged symmetricaly on each side. H.M. Weber (pers. comm. 2018) supports this attribution regarding our structures. Due to scarce material and the missing of commonly Y-shaped outlines, we opt to remain them among the indeterminate ossicles.

Ossicle type F. (Figs 7p-q) Sieve plates with many small, concentrically arranged pores, mostly with circular outline (Fig. 7p). A single ossicle with biconcave inner (?) margin ending in acute tips, and convex outer (?) margin (Fig. 7q). The ossicles resemble Eocaudina irregularis (Summerson \& Campbell, 1958) and Eocaudina sp. of Gao et al. (2012), which probably also belongs to E. irregularis.

Ossicle type G. (Figs 7r-t) Multilayered ossicles with relatively coarse-meshed stereom; complete elements circular in outline, but with one conspicuous indentation. On the outer (?) surface three prominent nodes arranged in a slightly arched row, which mimics the orientation of the indentation. Opposite surface plane. The tentatively assigned, relictic preserved ossicle from Figure $7 \mathrm{r}$ shows an identical stereomal structure. Zhang (1983) introduced similar ossicles from the early Carboniferous (Tournaisian) of China as Mortensenites teat. The taxon was also described by Ding (1985) from the late Carboniferous of China. The assignment of Mortensenites ossicles to holothurians was rejected by e.g. Pawson (1980) and Reich (2013).

\section{RESULTS AND CONCLUSIONS}

The microfacies of the studied samples of the upper and uppermost Genicera Fm. (Canalón Mb. and Millaró Beds) of North León confirms subphotic pelagic deeper water environments well below storm-wave base with a sufficiently oxygenated sea floor, which was a soft bottom according to the prevalence of mudstones and wackestones. Unexpectedly, they provided a diversified late Viséan to Serpukhovian autochthonous echinoderm fauna consisting of micro-ossicles of at least holothurians, stenuroids, ophiuroids, ophiocistioids, echinoids and pelmatozoans.

The holothurians comprise ossicles of both stem clades: The wheel-shaped ossicles, represented by the genera Langepis and Rotoides and by indeterminate palaeochiridotids reveal the presence of the Apodida; the sieve-plates, table plates and branched ossicles (Tetravirga) represent the sister clade Actinopoda. Within the Actinopoda, the Pneumonophora as well as the Elasipodida, which both should arise in the Devonian (Miller et al., 2017) are present. The Pneumonophora probably are proved by table ossicles and sieve plates; the Elasipodida at least by Tetravirga. The diversity of the Cantabrian fauna corroborates Reich (2010b), who stated the early diversification of the taxonomic higher ranks already during the Ordovician-Silurian interval, and the acme in the Middle Devonian with the appearance of the elasipodids. The fauna also supports Kozur \& Mostler (2008) who claimed that already one third of the presentday holothurian diversity existed in early Carboniferous times. Also Reich (2013) noted that the Carboniferous yielded the richest holothurian diversity of the Palaeozoic, 
altogether 65 paraspecies, but like before Reich (2010b), stressed the fact of a biased record due to taxonomic problems and widely missing studies.

Besides the holothurians, "arcaic" ophiuroids provided the most frequent ossicles. They, too, are represented by the known Palaeozoic stem groups. The Oegophiurida are proved by characteristic skeletal elements of Furcaster, including a new species of the paragenus Calclyra, the Stenurida by a distinct lateral arm plate of Pectenura. Elements of the ophiocistioids are very rare. They are represented by goniodonts assigned to Linguaserra, including the new species Linguaserra heidii n. sp. Within the pelmatozoans an allagecrinid microcrinoid was distinguished. Further indeterminate echinoderm ossicles are abundant and diverse.

In summary, the fauna stresses the importance of a pelagic deeper water echinoderm community of vagile and sessile taxa during the Carboniferous. It strongly reminds of the abundance and diversity of echinoderms in modern pelagic, psychrospheric environments. Therefore, the roots of this exceptionally conservative community are in the Palaeozoic (Pabst \& Herbig, 2018, 2019).

However, the Mississippian pelagic environment is strongly underexplored, as most echinoderm ossicles have been derived from shallow-water environments and even description of these associations are rare. They are known from Scotland (Etheridge, 1881), Belgium (Weber \& Aretz, 2000), Germany (Haude \& Thomas, 1994; Weber, 1997), Austria (Schraut, 1995), Poland (Alexandrowicz, 1971), Slovakia (Kozur et al., 1976), Iran (Nouredini et al., 2015), Afghanistan (Mostler, 1971a; Reich \& Mostler, 2002), China (Zhang, 1983, 1985, 1986a, 1986b, 1993), and the USA (e.g. Croneis \& McCormack, 1932; Gutschick, 1959; Gutschick et al., 1967). However, opposed to the herein first reported Upper Mississippian fauna of the Cantabrian Mountains, they belong to tropical carbonate platforms. The same is true for the Pennsylvanian, e.g. for noncrinoid faunas described from Hungary (Kozur, 1984a, 1984b), USA (e.g. Frizzell \& Exline, 1956, 1966), China (e.g. Ding, 1985; Zhang, 1993) and North Spain (Bless \& Sánchez de Posada, 1971; Zamora, 2016).

\section{ACKNOWLEDGEMENTS}

We are indebted to M. Reich (Munich) for his valuable advices and comments on an earlier version of the manuscript and to H.M. Weber (Bergisch-Gladbach) for several taxonomical precisions. G.D. Sevastopulo is acknowledged for his hint to the occurrence of the allagecrinid ossicles. We are also much obliged to the reviewers M. Reich (Munich) and S. Zamora (Zaragoza) for detailed and useful comments and suggestions. We thank D. Lutzenkirchen for engaged assistance in the laboratory during his internship, and last, but not least, R. Bäumler for thorough preparation of the thin-sections and H. Ciezynski for splendid SEM photographs.

\section{REFERENCES}

Aboussalam, Z.S. 2003. Das "Taghanic-Event" im höheren Mittel-Devon von West-Europa und Marokko. Münstersche Forschungen zur Geologie und Paläontologie, 97, 1-332.

Alexandrowicz, Z. 1971. Carboniferous Holothuroidea sclerites in the Upper Silesia Coal Basin (Southern Poland). Rocznik Polskiego Towarzystwa Geologicznego [= Annales de la Société Géologique de Pologne], 41, 281-291.

Amler, M.R.W. \& Winkler Prins, C.F. 1999. Lower Carboniferous marine bivalves from the Cantabrian Mountains (Spain). Scripta Geologica, 120, 1-35.

Ausich, W.I. 2001. Echinoderm taphonomy. In: Echinoderm Studies (eds Jangoux, M. \& Lawrence, J.M.), A.A. Balkema, Rotterdam, 6, 171-227.

Balthasar, U. \& Amler, M.R.W. 2003. Silicified foraminifera from the Lower Carboniferous Genicera Formation (Cantabrian Mountains, Northern Spain) and their palaeoenvironmental interpretation. Courier Forschungsinstitut Senckenberg, 242, 1-19.

Bábek, O., Kalvoda, J., Aretz, M., Cossey, P.J., Devuyst, X., Herbig, H.-G. \& Sevastopulo, G. 2010. The correlation potential of magnetic susceptibility and outcrop gammaray logs at Tournaisian-Viséan boundary sections in Western Europe. Geologica Belgica, 13, 291-208.

Barrois, Ch. 1882. Recherches sur les terrains anciens de Asturies et de la Galice. Mémoirs de la Société Géologique $d u$ Nord, 2, 1-630.

Blake, D.B. 2013. Early Asterozoan (Echinodermata) diversification: a paleontologic quandary. Journal of Paleontology, 87, 353-372; doi: 10.1666/12-042.1.

Bless, M.J.M. \& Sánchez de Posada, L. 1971. Restos de Asterozoa en el Westfaliense superior de Asturias. Breviora Geológica Astúrica, 15, 13-16.

Boczarowski, A. 1997. Mistaken identity of wheel-shaped sclerites of Ophiocistioidea and Holothuroidea. Slovak Geological Magazine, 3, 331-340.

Boczarowski, A. 2001. Isolated sclerites of Devonian nonPelmatozoan echinoderms. Palaeontologica Polonica, 59, 1-219.

Bohatý, J. \& Herbig, H.-G. 2010. Middle Givetian echinoderms from the Schlade Valley (Rhenish Massif, Germany): habitats, taxonomy and ecostratigraphy. Paläontologische Zeitschrift, 84, 365-385.

Bourrouilh, R. \& Termier, G. 1973. Balearocrinus breimeri, crinoide nouveau du Viséen superior de Minorca (Baleares). Annales de la Société geologique du Nord, 93, 225- 232.

Brandt, J.F. 1835. Prodromus descriptionis animalium ab H. Mertensio in orbis terrarum circumnavigatione 
observatorum. In: Animalia Mertensii. St. Petersburg, Fasc. 1, 75 pp.

Breimer, A. 1962. A monograph on Spanish Paleozoic Crinoidea. Leidse Geologische Mededelingen, 27, 1-190.

Bruguière, J.G. 1791. Tableau Encyclopédique et Méthodique des Trois Règnes de la Nature. Contenant l'Helminthologie, ou les vers Infusoires, les vers Intestins, les vers Mollusques, etc. Septième Livrasion. C.F. Panckoucke, Paris, viii +132 pp.

Colmenero, J.R., Fernández, L.P., Moreno, C., Bahamonde, J.R., Barba, P., Heredia, N. \& González, F. 2002. Carboniferous. In: The Geology of Spain (eds Gibbons, W. \& Moreno, M.T.). Geological Society, London, 93-116.

Comte, P. 1959. Recherches sur les terrains anciens de la Cordillère Cantabrique. Memorias del Instituto Geológico y Minero de España, 60, 1-440.

Cózar, P., Somerville, I.D., Sanz-López, J. \& Blanco-Ferrera, S. 2016. Foraminiferal biostratigraphy across the Visean/ Serpukhovian boundary in the Vegas de Sotres section (Cantabrian Mountains, Spain). Journal of Foraminiferal Research, 46, 171-192; doi: 10.2113/gsjfr.46.2.171.

Croneis, C. \& McCormack, J. 1932. Fossil Holothuroidea. Journal of Paleontology, 6, 111-148.

de Blainville, H.M.D. 1834. Manuel d'Actinologie ou de Zoophytologie. F.G. Levrault, Paris, 695 pp.

Ding, H. 1985. Discovery of holothurian sclerites from the Taiyuan Formation (Upper Carboniferous), Henan, China. Acta Micropalaeontologica Sinica, 2, 339-348 (in Chinese with English abstract).

Ebner, F. \& Fenninger, A. 1980. Mikrofazies und Biostratigraphie der Kalkgerölle von Falcovec (NW Bulgarien). Paleontologiya, Stratigrafiya i Lithologiya, Bulgarska Akademiiâ na Naukite, 12, 3-12.

Eichmüller, K. \& Seibert, P. 1984. Faziesentwicklung zwischen Tournai und Westfal D im Kantabrischen Gebirge (NW-Spanien). Zeitschrift der Deutschen Geologischen Gesellschaft, 135, 163-191.

Etheridge, R., Jr. 1881. On the presence of the scattered skeletal remains of Holothuroidea in the Carboniferous Limestones Series of Scotland. Proceedings of the Royal Philosophical Society of Edinburgh, 6, 183-193.

Frizzell, D. \& Exline, H. 1956. Monograph of fossil holothurian sclerites. Bulletin of the Missouri University School of Metallurgy and Mines, Technical Series, 89 [1955], 1-204.

Frizzell, D. \& Exline, H. 1966. Holothuroidea - fossil record. In: Treatise on Invertebrate Paleontology. Part U. Echinodermata (ed. Moore, R. C.). Geological Society of America and University of Kansas Press, 3 (2), U646U672.

Gandl, J. 1977. Die Trilobiten der Alba-Schichten (Unter-Visé bis Namur A). Senckenbergiana lethaea, 58, 113-217.

Gao, L., Ding, H., Zhang, P., Wang, Y. \& Sun, J. 2012. Discovery of Carboniferous holothurian sclerites from the Benxi Formation, Pingshuo Mining Area, Shanxi Province. Acta Micropalaeontologica Sinica, 29, 179-194.

García-Bellido, D. 2002. Poríferos fósiles del Paleozoico de la Península Ibérica. Ph.D. Thesis, Unversidad Complutense de Madrid, 183 pp.
García-Bellido, D. \& Rigby, J. 2004. Devonian and Carboniferous sponges from Spain. Journal of Paleontology, 78, 431-455.

García-López, S. \& Sanz-López, J. 2002. Devonian to Lower Carboniferous conodont biostratigraphy of the Bernesga Valley section (Cantabrian Zone, NW-Spain). In: Palaeozoic Conodonts from Northern Spain (eds García-López, S. \& Bastida, F.). Cuadernos del Museo Geominero, 1, 125-162.

García-López, S. \& Truyols, J. 1974. Presencia de escleritos de holoturoideos en las calizas Devónicas de la Cordillera Cantábrica. Breviora Geológica Astúrica, 1974, 17-20.

Gilliland, P.M. 1992. Holothurians in the Blue Lias of southern Britain. Palaeontology, 35, 159-210.

Gilliland, P.M. 1993. The skeletal morphology, systematic and evolutionary history of holothurians. Special Papers in Palaeontology, 47, 147 pp.

Gray, J.E. 1840. A synopsis of the genera and species of the class Hypostoma Asterias (Linn.). Annals and Magazine of Natural History, 6, 275-290.

Grube, A.E. 1840. Actinien, Echinodermen und Würmer des Adriatischen-und Mittelmeers. J. H. Bon, Königsberg, $92 \mathrm{pp}$.

Gutschick, R.C. 1954. Holothurian sclerites of the Middle Ordovician of northern Illinois. Journal of Paleontology, 28, 827-829

Gutschick, R.C. 1959. Lower Mississippian holothurian sclerites from the Rockford Limestone of northern Indiana. Journal of Paleontology, 33, 130-137.

Gutschick, R.C. \& Canis, W.F. 1971. The holothurian sclerite genera Cucumarites, Eocaudina, and Thuroholia. Re-study of Eocaudina and Protocaudina from the Devonian of Iowa. Journal of Paleontology, 45, 327-337.

Gutschick, R.C. \& Sandberg, C.A. 1983. Mississippian continental margins of the conterminous United States. In: The Shelfbreak: Critical Interface on Continental Margins (eds Stanley, D.J. \& Moore, G.T.). Society of Economic Paleontologists and Mineralogists, Special Publication, 33, 79-96.

Gutschick, R.C., Canis, W.F. \& Brill, K.G., Jr. 1967. Kinderhookian (Mississippian) holothurian sclerites from Montana and Missouri. Journal of Paleontology, 41, 1461-1480.

Haude, R. 1982. Ophiuren (Echinodermata) aus dem Karbon des Rheinischen Schiefergebirges. Geologisches Jahrbuch Hessen, 110, 5-26.

Haude, R. \& Langenstrassen, F. 1976a. Rotasaccus dentifer n. g. n. sp., ein devonischer Ophiocistioide (Echinodermata) mit holothuroiden Wandskleriten und echinoidem Kauapparat. Paläontologische Zeitschrift, 50, 130-150.

Haude, R. \& Langenstrassen, F. 1976b. Winkelzähne und Ophiocistioiden aus Silur, Devon und Karbon. Lethaia, 9, 179-184.

Haude, R. \& Thomas, E. 1994. Eleutherozoen (Echinodermata) aus dem Unterkarbon von Aprath im Bergischen Land. Archäologie im Ruhrgebiet, 2, 115-132.

Herbig, H.-G. 1982. Balearocrinus cantabricus n. sp. (Crinoidea, Inadunata) aus dem Visé des Kantabrischen 
Gebirges (Alba-Formation, Prov. León/NW-Spanien). Neues Jahrbuch für Geologie und Paläontologie, Monatshefte, 1982, 476-484.

Herbig, H.-G. 1994. Remarks on the Late Viséan crinoids from the Cantabrian Mountains and Menorca (NW Spain and Balearic Islands). Revista Española de Paleontología, 9, 24-28.

Herbig, H.-G. 2016. Mississippian (Early Carboniferous) sequence stratigraphy of the Rhenish Kulm Basin, Germany. Geologica Belgica, 19, 81-110; doi: 10.20341/ gb.2016.010.

Herbig, H.-G, Pabst, J. \& Könen, J. 2011. The enigma of Mississippian pelagic carbonate environments approached by agglutinating foraminifera and carbonate microfacies. In: Programme and Abstracts: the XVII International Congress on the Carboniferous and Permian, 3-8 July 2011, Perth, W.A. (eds Håkansson, E. $\&$ Trotter, J.A.). Geological Survey of Western Australia, 2011 (20), p. 68.

Higgins, A.C. 1971. Conodont biostratigraphy of the Late Devonian-Early Carboniferous rocks of the south central Cantabrian Cordillera. Trabajos de Geología, Universidad de Oviedo, 4, 179-192.

Higgins, A.C. \& Wagner-Gentis, C.H.T. 1982. Conodonts, goniatites and biostratigraphy of the earlier Carboniferous from the Cantabrian Mountains, Spain. Palaeontology, 25, 313-350.

Higgins, A.C., Wagner-Gentis, C.H.T. \& Wagner, R.H. 1964. Basal Carboniferous strata in part of northern León, NW Spain: stratigraphy, conodont and goniatite faunas. Bulletin de la Société belge de Géologie, Paléontologie et Hydrologie, 72 (1963), 205-248.

Hunter, A.W. \& McNamara, K.J. 2018. Prolonged co-existence of 'archaic' and 'modern' Palaeozoic ophiuroids - evidence from the early Permian, Southern Carnarvon Basin, Western Australia. Journal of Systematic Palaeontology, 16, 891-907; doi: 10.1080/14772019.2017.1353549.

Joysey, K.A. \& Breimer, A. 1963. The anatomical structure and systematic position of Pentablastus (Blastoidea) from the Carboniferous of Spain. Palaeontology, 6, 471-490.

Julivert, M. 1971. Decollement tectonics in the Hercynian Cordillera of NW Spain. American Journal of Science, 270, 1-29.

Keller, M., Bahlburg, H. \& Reuther, C.-D. 2008. The transition from passive to active margin sedimentation in the Cantabrian Mountains, Northern Spain: Devonian or Carboniferous? Tectonophysics, 461, 414-427; doi: 10.1016/j.tecto.2008.06.022.

Klein, J.T. 1734. Naturalis Dispositio Echinodermatum. Accessit Lucubratiuncula de Aculeis Achinorum Marinorum, cum Spicilegio de Belemnitis. T.J. Schreiber, Danzig, 78 pp.

Kornicker, L.S. \& Imbrie, J. 1958. Holothurian sclerites from the Florena shale (Permian) of Kansas. Micropaleontology, 4, 93-96.

Kozur, H. 1984a. Biostratigraphic evaluation of the Upper Paleozoic conodonts, ostracods and holothurian sclerites of the Bükk Mts. Part I: Carboniferous conodonts and holothurian sclerites. Acta Geologica Hungarica, 27, 143-162.

Kozur, H. 1984b. A Nagybátony-324. sz. fúrás oligocén elötti képzödményeinek rétegtani besorolása és tektonikai értékelése. Földtani Közlöny, Bulletin of the Hungarian Geological Society, 114, 61-79 (in Hungarian with German abstract).

Kozur, H. \& Mostler, H. 1989. Echinoderm remains from the Middle Permian (Wordian) from Sosio Valley (Western Sicily). Jahrbuch der Geologischen Bundesanstalt Wien, 132, 677-685.

Kozur, H. \& Mostler, H. 2008. Neue Holothurien-Sklerite aus dem unteren Wordian vom Nordwestrand des Delaware Beckens am Südosthang der Guadalupe Mountains (WestTexas, USA). GeoAlp, 5, 107-119.

Kozur, H., Mock, R. \& Mostler, H. 1976. Stratigraphische Neueinstufung der Karbonatgesteine der „unteren Schichtfolge" von Ochtiná (Slowakei) in das oberste Visé und Serpukhovian (Namur A). GeologischPaläontologische Mitteilungen Innsbruck, 6, 1-29.

Kullmann, J. \& Schönenberg, R. 1975. Geodynamische und paläökologische Entwicklung im Kantabrischen Variszikum (Nordspanien). Ein interdisziplinäres Arbeitskonzept. Neues Jahrbuch für Geologie und Paläontologie, Monatshefte, 1975, 151-166.

Kullmann, J., Reuther, C.-D. \& Schönenberg, R. 1977. La transición del estado geosinclinal a la orogénesis en la formación varíscica de la Cordillera Cantábrica. Breviora Geológica Astúrica, 21, 4-11.

Lane, N.G. \& Sevastopulo, G.D. 1981. Functional morphology of a microcrinoid: Kallimorphocrinus punctatus n. sp. Journal of Paleontology, 55, 13-28.

Langenheim, R.L., Jr., \& Epis, R.C. 1957. Holothurian sclerites from the Mississippian Escabrosa Limestone, Arizona. Micropaleontology, 3, 165-170.

Langer, W. 1991. Beiträge zur Mikropaläontologie des Devons im Rheinischen Schiefergebirge. Geologisches Jahrbuch, Reihe A, 128, 35-65.

Lotze, F. 1945. Zur Gliederung der Varisziden der Iberischen Meseta. Geotektonische Forschungen, 6, 78-92.

Ludwig, H. 1889-1892. Echinodermen. Die Seewalzen. In: Dr. H.G. Bronn's Klassen und Ordnungen des Thier-Reiches, Wissenschaftlich Dargestellt in Wort und Bild. Winter'sche Verlagshandlung, Leipzig, 2 (3), 460 pp.

Ludwig, H. 1891. Ankyroderma musculus (Risso), eine Molpadiide des Mittelmeeres, nebst Bemerkungen zur Phylogenie und Systematik der Holothurien. Zeitschrift für wissenschaftliche Zoologie, 51, 569-612.

Mamet, B. \& Boulvain, F. 1991. Constructions hématitiques de griottes carbonifères (Asturies, Espagne). Bulletin de la Société belge de Géologie, 99, 199-211.

Marcos, A. \& Pulgar, J.A. 1982. An approach to the tectonostratigraphic evolution of the Cantabrian foreland thrust and fold belt, Hercynian Cordillera of NW Spain. Neues Jahrbuch für Geologie und Paläontologie, Abhandlungen, 163, 256-260.

Martin, W.R. 1952. Holothuroidea of the Iowa Devonian. Journal of Paleontology, 26, 728-729. 
Matsumoto, H. 1915. A new classification of Ophiuroidea: with description of genera and species. Proceedings of the Academy of Natural Sciences of Philadelphia, 67, 43-92.

Matyja, B.A., Matyja, H. \& Szulczewski, M. 1973. The genus Eocaudina Martin (Holothuroidea) from the Devonian of Poland. Acta Geologica Polonica, 23, 135-147.

Miller, A.K., Kerr, A.M., Paulay, G., Reich, M., Wilson, N.G., Carvajal, J.I. \& Rouse, G.W. 2017. Molecular phylogeny of extant Holothuroidea (Echinodermata). Molecular Phylogenetics and Evolution, 111, 110-131; doi: 10.1016/j.ympev.2017.02.014.

Morris, P.G. 1992. Rhabdocrinus scotocarbonarius (Wright), a crinoid from the Carboniferous "griotte" limestone of Palencia, Northwest Spain. Revista Española de Paleontología, 7, 181-184.

Mostler, H. 1968a. Neue Holothurien-Sklerite aus den norischen Hallstätter Kalken (Nördlichen Kalkalpen). Berichte des Naturwissenschaftlichen-Medizinischen Vereins Innsbruck, 56, 427-441.

Mostler, H. 1968b. Holothurien-Sklerite aus oberanisischen Hallstätterkalken (Ostalpen, Bosnien, Türkei). Veröffentlichungen der Universität InnsbruckAlpenkundliche Studien, 2, 5-45.

Mostler, H. 1971a. Mikrofauna aus dem Unter-Karbon vom Hindukusch. Geologisch-Paläontologische Mitteilungen Innsbruck, 1, 1-19.

Mostler, H. 1971b. Ophiurenskelettelemente (äußere Skelettanhänge) aus der alpinen Trias. GeologischPaläontologische Mitteilungen Innsbruck, 1, 1-35.

Mostler, M. \& Rahimi-Yazd, A. 1976. Neue Holothuriensklerite aus dem Oberperm von Julfa im Nordiran. GeologischPaläontologische Mitteilungen Innsbruck, 5, 1-35.

Nemyrovska, T.I. 2005. Late Viséan/early Sepukhovian conodont succession from the Triollo section, Palencia (Cantabrian Mountains, Spain). Scripta Geologica, 129, 13-89.

Nemyrovska, T.I., Wagner, R.H., Winkler Prins, C.F. \& Montañez, I. 2011. Conodont faunas across the midCarboniferous boundary from the Barcaliente Formation at La Lastra (Palentian Zone, Cantabrian Mountains, northwest Spain); geological setting, sedimentological characters and faunal descriptions. Scripta Geologica, 143, 127-183.

Nouredini, M., Yazdi, M., Ashouri, A.R., \& Rahmanti, S. 2015. Lower Carboniferous holothurian sclerites from the Banarizeh Section, Southeast Isfahan. Geosciences, 24, 165-174 (in Farsi with English abstract); doi: 10.22071/ GSJ.2015.42308.

O'Hara, T.D., Hugall, A.F., Thuy, B., Stöhr, S. \& Martynov, A.V. 2017. Restructuring higher taxonomy using broadscale phylogenomics: the living Ophiuroidea. Molecular Phylogenetics and Evolution, 107, 415-430; doi: 10.1016/j.ympev.2016.12.006.

Östergren, H.J. 1907. Zur Phylogenie und Systematik der Seewalzen. Särtryck ur Zoologiska Studier, 1, 191-215.

Pabst, J. \& Herbig, H.-G. 2018. Vagile echinoderms from a Carboniferous pelagic environment - Evidence for the antiquity of the modern deep-water fauna. In: Book of
Abstracts: GeoBonn 2018 - Living Earth, 2-6 September 2018, Bonn. Dachverband Geowissenschaften, p. 264.

Pabst, J. \& Herbig, H.-G. 2019. A pelagic echinoderm microfauna from the Serpukhovian of the southern Cantabrian Mountains (Province León, NW Spain). In: 19th International Congress on the Carboniferous and Permian, Cologne, July 29-August 2, 2019, Abstracts (eds Hartenfels, S., Herbig, H.-G., Amler, M.R.W. \& Aretz, M.). Kölner Forum für Geologie und Paläontologie, 23, 252-253.

Pawson, D.L. 1966. Phylogeny and evolution of holothuroids. In: Treatise on Invertebrate Paleontology. Part $U$, Echinodermata (ed. Moore, R.C.). Geological Society of America and University of Kansas Press, Boulder/ Colorado and Lawrence/Kansas, 3 (2), U641-U646.

Pawson, D.L. 1980. Holothuroidea. In: Echinoderms: Notes for a Short Course (eds Broadhead, T.W. \& Waters, J.A.). University of Tennessee, Department of Geological Sciences, Studies in Geology, 3, 175-189.

Pérez-Estaún, A., Bastida, F., Alonso, J.L., Marquínez, J., Aller, J., Álvarez-Marrón, J., Marcos, A. \& Pulgar, J.A. 1988. A thin-skinned tectonics model for an arcuate fold and thrust belt: The Cantabrian Zone (Variscan IberoArmorican Arc). Tectonics, 7, 517-537; doi: 10.1029/ TT007i003p00517.

Prado, C. \& de Verneuil, E. 1850. Sur les terrains de Sabero et des environs dans les Montagnes de León (Espagne). Bulletin de la Société Géologique de France, $2^{i m e}$ série, 7, 137-155.

Reich, M. 2007. Linguaserra spandeli sp. nov. (Echinodermata: Ophiocistioidea) from the Late Permian (Zechstein) of Thuringia, Germany. Annales de Paléontologie, 93, 317-330; doi: 10.1016/jannpal.2007.09.007.

Reich, M. 2010a. Evolution and diversification of ophiocistioids (Echinodermata: Echinozoa). Echinoderms: Durham. Proceedings of the 12th International Echinoderm Conference, 7-11 August 2006, Durham/New Hampshire (eds Harris, L.G., Böttcher, S.A., Walker, C.W. \& Lesser, M.P.). CRC Press, Taylor \& Francis, 51-54.

Reich, M. 2010b. The early evolution and diversification of holothurians (Echinozoa). In: Echinoderms: Durham. Proceedings of the 12th International Echinoderm Conference, 7-11 August 2006, Durham/New Hampshire (eds Harris, L.G., Böttcher, S.A., Walker, C.W. \& Lesser, M.P.). CRC Press, Taylor \& Francis, 55-59.

Reich, M. 2012. On Mesozoic laetmogonid sea cucumbers (Echinodermata: Holothuroidea: Elasipodida). Zoosymposia, 7, 185-212; doi: 10.11646/ zoosymposia.7.1.18.

Reich, M. 2013. How many species of fossil holothurians are there? In: Echinoderms in a Changing World. Proceedings of the 13th International Echinoderm Conference, 5-9 January 2009, Hobart/Tasmania (ed. Johnson, C.). CRC Press, Taylor \& Francis, 23-51.

Reich, M. \& Haude, R. 2004. Ophiocistioidea (fossil Echinodermata): an overview. In: Echinoderms: München. Proceedings of the 11th international Echinoderm Conference, 6-10 October 2003, Munich (eds Heinzeller, 
T. \& Nebelsick, J.H.). CRC Press, Taylor \& Francis, 489-494.

Reich, M. \& Kutscher, M. 2014. A new ophiocistioid (Echinodermata) from the Silurian of Gotland, Sweden. GFF, 136, 459-463; doi: 10.1080/11035897.2013.861863.

Reich, M. \& Mostler, H. 2002. Gillocystis (Echinodermata) aus dem Unter-Karbon Afghanistans. Neues Jahrbuch für Geologie und Paläontologie, Monatshefte, 2002, 588-596.

Reich, M. \& Smith, A.B. 2009. Origins and biomechanical evolution of teeth in echinoids and their relatives. Palaeontology, 52, 1149-1168; doi: 10.1111/j.14754983.2009.00900.x.

Reich, M., Stegemann, T.R., Hausmann, I, Roden, V.J. \& Nützel, A. 2018. The youngest ophiocistioid: A first Palaeozoic-type echinoderm group representative from the Mesozoic. Palaeontology, 61, 803-811; doi: 10.1111/ pala. 12392.

Reuther, C.D. 1977. Das Namur im südlichen Kantabrischen Gebirge (Nordspanien). Krustenbewegungen und Faziesdifferenzierung im Übergang GeosynklinaleOrogen. Clausthaler geologische Abhandlungen, 28, $1-122$.

Sánchez de Posada, L.C., Martínez Chacón, M.L., Méndez, C.A., Menéndez-Álvarez, J.R. Río, L.M., Rodríguez, S., Truyols, J. \& Villa, E. 1996. El Carbonífero marino del ámbito astur-leonés (Zona Cantábrica): síntesis paleontológica. Revista Española de Paleontología, $\mathrm{N}^{\circ}$ Extraordinario, 82-96.

Sandberg, C. \& Gutschick, R.C. 1984. Distribution, microfauna, and source-rock potential of Mississippian Delle Phosphatic Member of Woodman Formation and equivalents, Utah and adjacent States. In: Hydrocarbon Source Rocks of the Greater Rocky Mountain Region (eds Woodward, J., Meissner, F.F. \& Clayton, J.L.). Rocky Mountain Association of Geologists, Denver, 135-178.

Sanz-López, J., Blanco-Ferrera, S. \& Sánchez de Posada, L.C. 2004. Estratigrafía del Serpukhoviense y el Bashkiriense inferior (Carbonífero) en la provincia de Pliegues y Mantos, Zona Cantábrica. In: VI Congreso Geológico de España, Zaragoza, 12-15 Julio 2004 (eds Liesa Carrera, C.L., Pocovi Juan, A., Sancho Marcén, C., Colombo Piñol, F., González Rodríguez, A. \& Soria de Miguel, A.R.). Geo-Temas, 6, 131-134.

Sanz-López, J., Blanco-Ferrera, S., Sánchez de Posada, L.C. \& García.López, S. 2007. Serpukhovian conodonts from Northern Spain and their biostratigraphic application. Palaeontology, 50, 883-904; doi: 10.1111/j.14754983.2007.00684.x.

Sanz-López, J., Blanco-Ferrera, S., Cózar, P. \& Nikolaeva, S.V. 2019. The Millaró stratigraphic section, a potential candidate for the GSSP of the Viséan/Serpukhovian boundary from the Cantabrian Mountains (Spain). In: 19th International Congress on the Carboniferous and Permian, Cologne, July 29-August 2, 2019, Abstracts (eds Hartenfels, S., Herbig, H.-G., Amler, M.R.W. \& Aretz, M.). Kölner Forum für Geologie und Paläontologie, 23, 275-276.
Schlumberger, C. 1890. Seconde note sur les holothuridées du Calcaire Grossier. Bulletin de la Société Géologique de France, 18, 191-206.

Schraut, G. 1995. Winkelzähne (Ophiocistioidea/ Echinodermata) aus dem Unter-Karbon von Nötsch/ Kärnten (Österreich). Jahrbuch der Geologischen Bundesanstalt, 136, 271-275.

Schulz, G. 1837. Note sur la géologie des Asturies. Bulletin de la Société Géologique de France, $1{ }^{\text {ère }}$ série, 8, 325-328.

Seibert, P. 1986. Fazies und paläogeographie des UnterKarbon (Alba Formation) im Kantabrischen Gebirge (Nordspanien). Ph.D. Thesis, Geowissenschaftliche Fakultät der Eberhard-Karls-Universität Tübingen, 208 pp.

Selenka, E. 1867. Beiträge zur Anatomie und Systematik der Holothurien. Zeitschrift für wissenschaftliche Zoologie, 17, 291-374.

Sevastopulo, G.D. 2008. Paleobiology of Carboniferous microcrinoids. In: Echinoderm Paleobiology (eds Ausich, W.I. \& Webster, G.D.). Indiana University Press, 55-69.

Sieverts-Doreck, H. 1951. Echinodermen aus dem spanischen Ober-Karbon. Paläntologische Zeitschrift, 24, 104-119.

Smirnov, A.V. 1998. On the classification of the apodid holothurians. In: Echinoderms: San Francisco (eds Mooi, R. \& Telford, M.). A.A. Balkema, Rotterdam, 517-522.

Smith, A.B. 1990. Biomineralization in echinoderms. In: Skeletal Biomineralization: Patterns, Processes and Evolutionary Trends (ed. Carter, J.G.). Van Nostrand Reinhold, New York, vol. 1, 170-175.

Sollas, W.J. 1899. Fossils in the University Museum, Oxford: I. On Silurian Echinoidea and Ophiuroidea. Quarterly Journal of the Geological Society, London, 55, 692-715.

Spandel, E. 1898. Die Echinodermen des deutschen Zechsteins. Abhandlungen der Naturhistorischen Gesellschaft zu Nürnberg, 11, 17-49.

Spencer, W.K. 1951. Early Palaeozoic starfish. Philosophical Transactions of the Royal Society of London, series B, 235 (B623), 87-129.

Stürtz, B. 1886. Über paläozoische Seesterne. Neues Jahrbuch für Mineralogie, Geologie und Paläontologie, 2, 142-154.

Summerson, C.H. \& Campbell, L.J. 1958. Holothurian sclerites from the Kendrick Shale of eastern Kentucky. Journal of Paleontology, 32, 961-969.

Théel, H. 1882. Report on the Holothurioidea dredged by H.M.S Challenger during the years 1873-1876, Part I. Report on the scientific results of the voyage of H.M.S. Challenger during the years 1873-76. Zoology, 4, $176 \mathrm{pp}$.

Ubaghs, G. 1966. Ophiocistioids. In: Treatise on Invertebrate Paleontology. Part U, Echinodermata (ed. Moore, R.C.). Geological Society of America and University of Kansas Press, Boulder/Colorado and Lawrence/Kansas, 3 (1), U174-U188.

Vachard, D., Perret, M.-F., Aguirre, P. \& Crasquin-Soleau, S. 1994. Micropaléontologie des calcaires épibathyaux à Globochaete (algue problèmatique) du Carbonifère des Pyrénées. Geobios, 27, 659-675; doi: 10.1016/S00166995(94)80053-7.

van Adrichem Boogaert, H.A. 1967. Devonian and Lower Carboniferous conodonts of the Cantabrian Mountains 
(Spain) and their stratigraphic application. Leidse Geologische Mededelingen, 39, 129-192.

von Zittel, K.A. 1895. Grundzüge der Palaeontologie. 971 pp. Wagner, R.H., Winkler Prins, C.F., Riding, R.E. \& WagnerGentis, C.H.T. 1971. Lithostratigraphic units of the lower part of the Carboniferous in northern León, Spain (with a note on some goniatite faunas). Trabajos de Geología, Universidad de Oviedo, 4, 603-663.

Weber, H.M. 1997. Holothurien- und Ophiocistioiden-Reste (Echinodermata) aus dem Unterkarbon des Velberter Sattels (Rheinisches Schiefergebirge). Sonderveröffentlichungen des Geologischen Instituts der Universität zu Köln, 114, 485-497.

Weber, H.M. \& Aretz, M. 2000. Außergewöhnliche Funde mikroskopischer Echinodermen-Reste aus dem belgischen Kohlenkalk (Unterkarbon). Terra Nostra, 2000/3 (70. Jahrestagung der Paläontologischen Gesellschaft. Vorträge und Poster. 24-30 September 2000 in Coburg), p. 123.

Webster, G.D., Maples, C.G., Sevastopulo, G.D., Frest, T. \& Waters, J.A. 2004. Carboniferous (Viséan-Moscovian) echinoderms from the Béchar Basin area of western Algeria. Bulletin of American Paleontology, 369, 1-98.

Wernlund, R.J. 1977. Biostratigraphy and paleoecology of holothurian sclerites from the Pinery Member, Bell Canyon Formation (Permian) of the Delaware Basin of West Texas. M.Sc. Thesis, Geosciences Faculty of Texas Tech University. $122 \mathrm{pp}$.

Wernlund, R.J. 1996. Taxonomy, distribution, and paleoecology of holothurians (Echinodermata) sclerites in Upper
Pennsylvanian cyclothem shales, North-Central Texas and South-Central Kansas. Ph.D. Thesis, Graduate Faculty of the Texas Tech University, $122 \mathrm{pp}$.

Zamora, S. 2016. Equinodermos del Paleozoico del norte de España. In: Actas de las XXXII Jornadas de la Sociedad Española de Paleontología (eds Meléndez, G., Núnez, A. \& Tomás, M.). Cuadernos del Museo Geominero, 20, 11-23.

Zankl, H. 1966. Holothurien-Sklerite aus dem Dachsteinkalk (Ober-Trias) der nördlichen Kalkalpen. Paläontologische Zeitschrift, 40, 70-88.

Zhang, J.-J. 1983. Some Holothuroidea fossils of early Carboniferous from Linwu, Hunan province. Oil \& Gas Geology, 4, 332-334 (in Chinese with English abstract).

Zhang. J.-J. 1985. Some Middle Devonian and Lower Carboniferous holothurian sclerites from Hunan. Hunan Geology [= Hunan dizhi], 4, 27-37 (in Chinese with English abstract).

Zhang, J.-J. 1986a. Lower Carboniferous holothurian sclerites from Hunan Province. Acta Micropalaeontologica Sinica, 3, 399-408 (in Chinese with English abstract).

Zhang, J.-J. 1986b. Lower Carboniferous holothurian sclerites from Menggongao Formation of central Hunan. Earth Science. Journal of Wuhan College of Geology $[=$ Diqiukexue. Wuhuan Dishi-xueyuan-xuebao], 11, 547-550.

Zhang, J.-J. 1993. Late Early Carboniferous Holothuroidea from Dushan, Guizhou. Acta Palaeontologica Sinica, 32, 105-114 (in Chinese with English abstract). 
